\title{
The Role of Epithelial-to-Mesenchymal Plasticity in Ovarian Cancer Progression and Therapy Resistance
}

\author{
Nele Loret ${ }^{1,2,3,4}$, Hannelore Denys ${ }^{2,5}$, Philippe Tummers ${ }^{2,3}$ and Geert Berx ${ }^{1,2, *}$ \\ 1 Molecular and Cellular Oncology Laboratory, Department of Biomedical Molecular Biology, \\ Ghent University, Technologiepark 71, 9052 Ghent, Belgium; nele.loret@ugent.be \\ 2 Cancer Research Institute Ghent (CRIG), 9000 Ghent, Belgium; Hannelore.Denys@UGent.be (H.D.); \\ philippe.tummers@ugent.be (P.T.) \\ 3 Department of Gynaecologic Oncology, Ghent University Hospital, C. Heymanslaan 10, 9000 Ghent, Belgium \\ 4 VIB Center for Inflammation Research, Technologiepark 71, 9052 Ghent, Belgium \\ 5 Department of Medical Oncology, Ghent University Hospital, C. Heymanslaan 10, 9000 Ghent, Belgium \\ * Correspondence: Geert.Berx@ugent.be
}

Received: 8 May 2019; Accepted: 12 June 2019; Published: 17 June 2019

\begin{abstract}
Ovarian cancer is the most lethal of all gynecologic malignancies and the eighth leading cause of cancer-related deaths among women worldwide. The main reasons for this poor prognosis are late diagnosis; when the disease is already in an advanced stage, and the frequent development of resistance to current chemotherapeutic regimens. Growing evidence demonstrates that apart from its role in ovarian cancer progression, epithelial-to-mesenchymal transition (EMT) can promote chemotherapy resistance. In this review, we will highlight the contribution of EMT to the distinct steps of ovarian cancer progression. In addition, we will review the different types of ovarian cancer resistance to therapy with particular attention to EMT-mediated mechanisms such as cell fate transitions, enhancement of cancer cell survival, and upregulation of genes related to drug resistance. Preclinical studies of anti-EMT therapies have yielded promising results. However, before anti-EMT therapies can be effectively implemented in clinical trials, more research is needed to elucidate the mechanisms leading to EMT-induced therapy resistance.
\end{abstract}

Keywords: ovarian cancer; epithelial-to-mesenchymal transition (EMT); mesenchymal-to-epithelial transition (MET); peritoneal metastasis; therapy resistance; cancer stem cell (CSC)

\section{Introduction}

In 2018, the worldwide age-standardized incidence of ovarian cancer was 6.6/100,000 [1]. With an overall five-year survival rate of only $38-40 \%$, epithelial ovarian cancer (EOC) is the most lethal gynecologic malignancy [2,3], and the eighth leading cause of cancer-related deaths among women worldwide [1]. This poor prognosis is mainly due to late-stage diagnosis and the frequent development of resistance to current chemotherapy regimens $[4,5]$.

According to the WHO (World Health Organization) classification, there are seven main histological subtypes of EOC: high-grade and low-grade serous, mucinous, endometrioid, clear cell, Brenner, seromucinous, and undifferentiated carcinomas [6,7]. The high-grade serous (HGS) subtype, of which the majority $(>80 \%)$ arise from the fallopian tube epithelium [8], is responsible for the largest number of ovarian cancer deaths $[9,10]$. The majority of HGS cancers are associated with TP53 mutations and approximately half of them have aberrant DNA repair via homologous recombination (because of genetic or epigenetic alterations of BRCA1/2 or other DNA repair molecules) [11,12]. On the other hand, low-grade serous carcinomas are mostly characterized by $B R A F$ - and KRAS-mutations [12]. The typical molecular alterations found in the other subtypes are KRAS-, CDKN2A- and TP53-mutations for the 
mucinous subtype, BRAF-, PTEN-, ARID1A- and CTNNB1-mutations for the endometrioid subtype, and PIK3CA- and ARID1A-mutations for the clear cell ovarian carcinomas [13].

The extent of the disease is classified according to the FIGO (Fédération Internationale de Gynécologie et d'Obstétrique) staging system. In stage I, the tumor is confined to the ovaries or the fallopian tube(s), whereas in stage II the tumor has already extended to the pelvis (below the pelvic brim). However, most ovarian cancers are diagnosed in stage III when the tumor has already spread to the peritoneum outside the pelvis and/or the retroperitoneal lymph nodes. Stage IV is characterized by distant metastases other than peritoneal metastases. [14].

Current first-line treatment for epithelial ovarian cancer consists of complete debulking surgery combined with chemotherapy (carboplatin and paclitaxel). Although most patients initially respond well to primary combined treatment, about $80 \%$ relapse within five years [3]. This underscores the need to elucidate the mechanisms driving therapy resistance and to develop therapeutic strategies targeting the resistant relapse-inducing cancer cells.

\section{Epithelial-to-Mesenchymal Transition (EMT)}

\subsection{Definition of A Complex Process}

EMT is a reversible process by which epithelial cells lose their apical-basal polarity and cell-cell adhesion to become more spindle-shaped mesenchymal cells with increased migratory capacities. During this process, E-cadherin, an important component of adherens junctions, is repressed as well as occludins, claudins, Epcam, $\alpha 6 \beta 4$ integrin, and different cytokeratins, which are important for stabilization of desmosomes. Simultaneously, vimentin, fibronectin, neural cadherin (N-cadherin), $\beta 1$ and $\beta 3$ integrins, and matrix metalloproteinases (MMPs) are upregulated [15]. These mesenchymal-like cells can revert to their epithelial state, a process called mesenchymal-to-epithelial transition (MET) [15]. Moreover, recent evidence indicates that cancer cells can also be in an intermediate "partial EMT"-state with characteristics of both epithelial and mesenchymal cells [16-18].

Depending on the context in which EMT occurs, three types of EMT can be distinguished. Type I is important during embryogenesis, type II is observed during wound healing and fibrosis, and type III is associated with cancer progression [19]. Type III EMT drives the tumor-initiating- and metastasizing capacity of cancer cells as well as increased resistance to chemo- and immunotherapy [15]. Moreover, it makes cancer cells more resistant to anoïkis [20].

\subsection{EMT Transcription Factors}

EMT is regulated by a complex network of transcription factors that eventually lead to downregulation of epithelial genes and upregulation of mesenchymal genes. The leading EMT transcription factors are the zinc-finger E-box-binding homeobox factors Zeb1 and Zeb2, Snail (SNAI1), Slug (SNAI2), and the basic helix-loop-helix factors Twist1 and Twist2 [15,21-26]. Snail and Zeb transcription factors repress E-cadherin by directly binding it $[27,28]$.

\section{EMT and High-Grade Serous Ovarian Cancer Progression}

\subsection{The Role of EMT in HGS Ovarian Cancer Initiation}

As previously demonstrated in other tumor types, a small subset of "tumor initiating cells" has been identified in ovarian cancer [29-36]. These cells show mesenchymal- and stem cell-features, and are thought to drive tumor initiation [37]. The contribution of EMT to ovarian cancer initiation is indicated by the finding that induction of EMT caused repression of paired box protein 2 (PAX2), a transcription factor that preserves the differentiation state of oviductal epithelial cells. This in turn led to the development of HGS ovarian cancer precursor lesions, so-called secretory cell outgrowths (SCOUTS) and serous tubal intraepithelial carcinomas (STIC) [30]. This EMT and subsequent emergence 
of HGS ovarian cancer precursor lesions could be initiated by various stimuli, including TGF $\beta$, a potent EMT-inducer present in the follicular fluid, which is released during ovulation [30,38] (Figure 1).

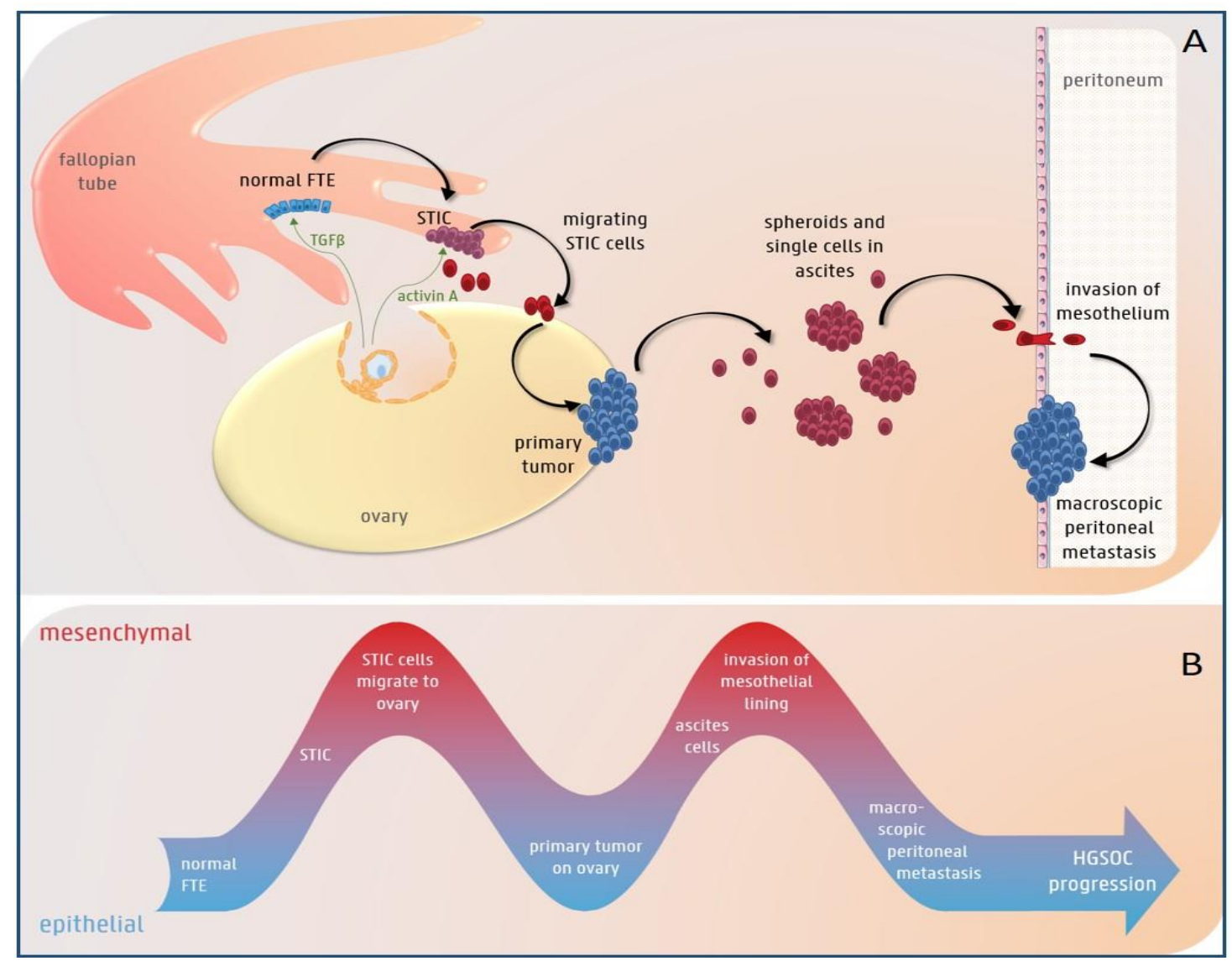

Figure 1. The potential role of epithelial-to-mesenchymal (EMT) plasticity during high-grade serous (HGS) ovarian cancer progression. (A) The color of the cells represents their EMT-state (blue = epithelial, purple $=$ spectrum of epithelial $/$ mesenchymal differentiation and red $=$ mesenchymal). TGF $\beta$ present in follicular fluid, which is released during ovulation, can induce EMT in the normal fallopian tube epithelium (FTE). This can lead to the development of STIC (serous tubal intraepithelial carcinoma) lesions. Acitivin A, another component of the follicular fluid, stimulates migration of the STIC cells to the ovary, where they undergo mesenchymal-to-epithelial transition (MET) and form a primary tumor. In a later stage, cells exfoliate from the primary tumor and survive as single cells or spheroids in the ascites. Finally, they invade the mesothelium and again undergo MET to form macroscopic peritoneal or omental metastases. (B) EMT plasticity with EMT and MET alternately taking place during HGS ovarian cancer progression.

Furthermore, there is growing evidence that loss of breast cancer type 1 susceptibility protein (BRCA1) is associated with EMT and tumor initiation. BRCA1 is a tumor suppressor that plays a role in the repair of double-stranded DNA breaks. Women with germline BRCA1 mutations have an inherited predisposition to breast- and ovarian cancer, with lifetime risks of $60-80 \%$ and 40-60\%, respectively [39-41]. They mainly develop aggressive, high-grade, and dedifferentiated tumor subtypes, such as triple negative breast cancers and HGS ovarian cancers, with loss of differentiation, aggressive behavior, and poor prognosis [41,42]. The link between BRCA1 and EMT in breast cancer has been demonstrated (reviewed in [41]), but so far it has not been investigated in ovarian cancer. In breast cancer, loss of BRCA1 results in dedifferentiation of mammary epithelial cells to a more stem cell like phenotype, with upregulation of CD44 and induction of EMT. Together with the ATPase-dependent chromatin remodeling protein (BRG1), and the Fanconi anemia group D2 protein 
(FANCD2), BRCA1 forms a complex important for inter-strand DNA crosslink repair and induction of $\triangle \mathrm{Np} 63$ expression [43]. $\triangle \mathrm{Np} 63$, a p63 isoform with pleomorphic functions, can prevent EMT in human mammary cells. This indicates that BRCA1-mediated DNA repair is important for maintaining a normal differentiation state and suppressing the development of breast- and ovarian cancer $[43,44]$. Indeed, reduced BRCA1 expression induced tumor-initiating cells, EMT, and stemness in breast cancer [45]. This association between BRCA1 and key molecules of EMT might explain why patients carrying mutations in BRCA1 develop mainly aggressive and dedifferentiated serous ovarian cancers. Nevertheless, this link still needs to be investigated in ovarian cancer.

\subsection{EMT Plasticity during HGS Ovarian Cancer Progression}

Growing evidence shows an important role for EMT in ovarian cancer metastasis [32,46-48]. In the next paragraph, we will highlight the contribution of EMT to the steps of ovarian cancer progression.

Once a STIC lesion has formed, cells exfoliate from the fimbriae and reach the ovarian surface, where they form an invasive carcinoma [49]. The migration of STIC cells to the ovary is an important step in HGS ovarian cancer progression (Figure 1). Notably, oophorectomy in a transgenic mouse model with fallopian tube-derived cancer reduced peritoneal metastases [50]. Indeed, the ovaries secrete many growth factors and hormones, such as TGF $\beta$ and activin A, which might attract cancer cells to the ovarian surface. Activin A, a member of the TGF $\beta$ superfamily present in the follicular fluid released during ovulation, induced EMT and stimulated migration of fallopian tube epithelium cells and HGS ovarian cancer cells by activation of the non-canonical PI3/AKT and MEK/ERK pathways [51]. This points to a pivotal role for activin A-induced EMT in the early stages of HGS ovarian cancer progression [51].

In the more advanced stages, cancer cells metastasize to the peritoneal cavity. In contrast to most epithelial cancers, ovarian cancer metastasizes mainly via a transcoelomic rather than a hematogenous route [52]. In this type of dissemination, cancer cells are shed from the primary tumor directly into the peritoneal cavity and survive as single cells or multi-cellular spheroids in the malignant intra-abdominal fluid, which is called ascites [53]. When tumor cells exfoliate from the primary tumor into the peritoneal fluid, they are exposed to insufficient cell-matrix interactions. This commonly triggers apoptotic cell death or anoikis in normal cells. EMT, induced by different stimuli such as TGF $\beta$ in ascites or by shear stress due to circulating ascites [54], can induce anoikis resistance, leading to survival of ovarian cancer cells in ascites (Figure 1) [55]. Indeed, exfoliated ascitic and metastatic ovarian cancer cells had increased Zeb2- and Akt2-expression compared to in situ lesions [56] and weaker E-cadherin expression compared to the primary tumor [57]. Thereafter, the circulating ascites disseminates the cancer cells into the abdominal cavity. Once the spheroids reach a secondary site, EMT induces upregulation of the fibronectin receptor, $\alpha 5 \beta 1$ integrin, which mediates their attachment to the mesothelial lining $[47,58]$. Indeed, spheroids with a mesenchymal or intermediate mesenchymal phenotype were more resistant to anoikis and invaded more easily than epithelial spheroids into the mesothelium [59]. After invading into the submesothelial matrix, cancer cells undergo the reverse process, MET, to grow out and form macroscopic peritoneal and omental metastases (Figure 1) [60-63]. These metastases are characterized by an E-cadherin expression level equal to or lower than that of the primary tumor $[61,64]$. Aside from this transcoelomic dissemination route, recent evidence points to the co-existence of a hematogenous dissemination route to the omentum via activation of the ErbB3-neuregulin1 (NRG1) pathway [65].

Growing evidence indicates that cells in a partial EMT-state are even more aggressive than cells with a complete mesenchymal phenotype, indicating that partial EMT might drive ascites formation and development of peritoneal metastases in ovarian cancer. Indeed, ovarian cancer cells in a hybrid epithelial/mesenchymal (E/M) state showed cancer stem cell (CSC) features and could drive tumor growth in vivo [66]. Moreover, ascites-associated multi-cellular aggregates with a "hybrid cadherin" phenotype, in which the cells are positive for both E-cadherin and N-cadherin, were more invasive than pure epithelial multi-cellular aggregates [67]. In addition, the intermediate mesenchymal subgroup 
of ovarian cancer cell lines, but not the mesenchymal subgroup, exhibited the strongest anoikis resistance, as well as migratory and invasive capacities in vitro and displayed high expression levels of Zeb1 [68]. These findings are supported by immunohistochemical stainings of human ovarian cancer samples, which showed that the serous subtype in particular is often double-positive for E-cadherin and vimentin [69].

Collectively, these findings provide evidence for the contribution of EMT plasticity to ovarian cancer progression. Ovarian cancer cells can alternately undergo EMT, possibly as a spectrum of states with both epithelial and mesenchymal differentiation, and MET at different stages of HGS ovarian cancer progression.

\subsection{The Role of EMT in Low-grade Serous Ovarian Cancer Initiation and Progression}

In contrast to HGS ovarian cancers, low-grade serous cancers are believed to arise in the ovary from serous cystadenomas. These evolve into non-invasive serous borderline tumors and then slowly and gradually into invasive low-grade serous cancers [70]. Although the oncogenic role of EMT in this subtype has been studied less extensively, there is some evidence that EMT might contribute to progression of low-grade serous ovarian cancers. Indeed, these tumors had elevated expression of EMT transcription factors such as Snail, Slug, Twist, Zeb, ZNF143, and ZNF281 [71,72]. Interestingly, ovarian surface epithelium (OSE) cells are mesothelial cells that can switch between epithelial and mesenchymal differentiation states, which is important for repairing the ovarian surface after ovulation [73]. Furthermore, EMT might contribute to the progression of non-invasive serous borderline tumors to invasive low-grade serous cancers. Indeed, knockdown of p53 stimulated invasion of serous borderline ovarian tumor cells in vitro by PI3K/Akt-mediated downregulation of E-cadherin [74].

\section{EMT and Chemotherapy Resistance}

The first-line chemotherapy treatment for patients with EOC consists of carboplatin combined with paclitaxel. Platinum agents such as cisplatin and carboplatin (a less nephrotoxic and neurotoxic cisplatin derivative [75]) form DNA cross-links and platinum adducts between DNA and proteins, which causes DNA damage and subsequent cell death $[76,77]$. Paclitaxel induces cell death by binding the $\beta$-tubulin subunit of microtubuli, thus causing microtubule dysfunction and subsequent cell cycle arrest [78].

Working on distinct molecular mechanisms, carboplatin, and paclitaxel act synergistically and eliminate most tumor cells during the initial treatment phase. However, $80 \%$ of ovarian cancer patients relapse within five years [3]. This emphasizes the need for deeper insight into the molecular mechanisms leading to therapy resistance.

Several in vitro and in vivo studies show that cancer cells that are resistant to carboplatin and/or paclitaxel acquire a mesenchymal phenotype, which points to EMT as a driver of resistance to therapy [79-83]. In the following paragraphs, we will discuss the different EMT-driven mechanisms that can lead to chemoresistance (Figure 2). 


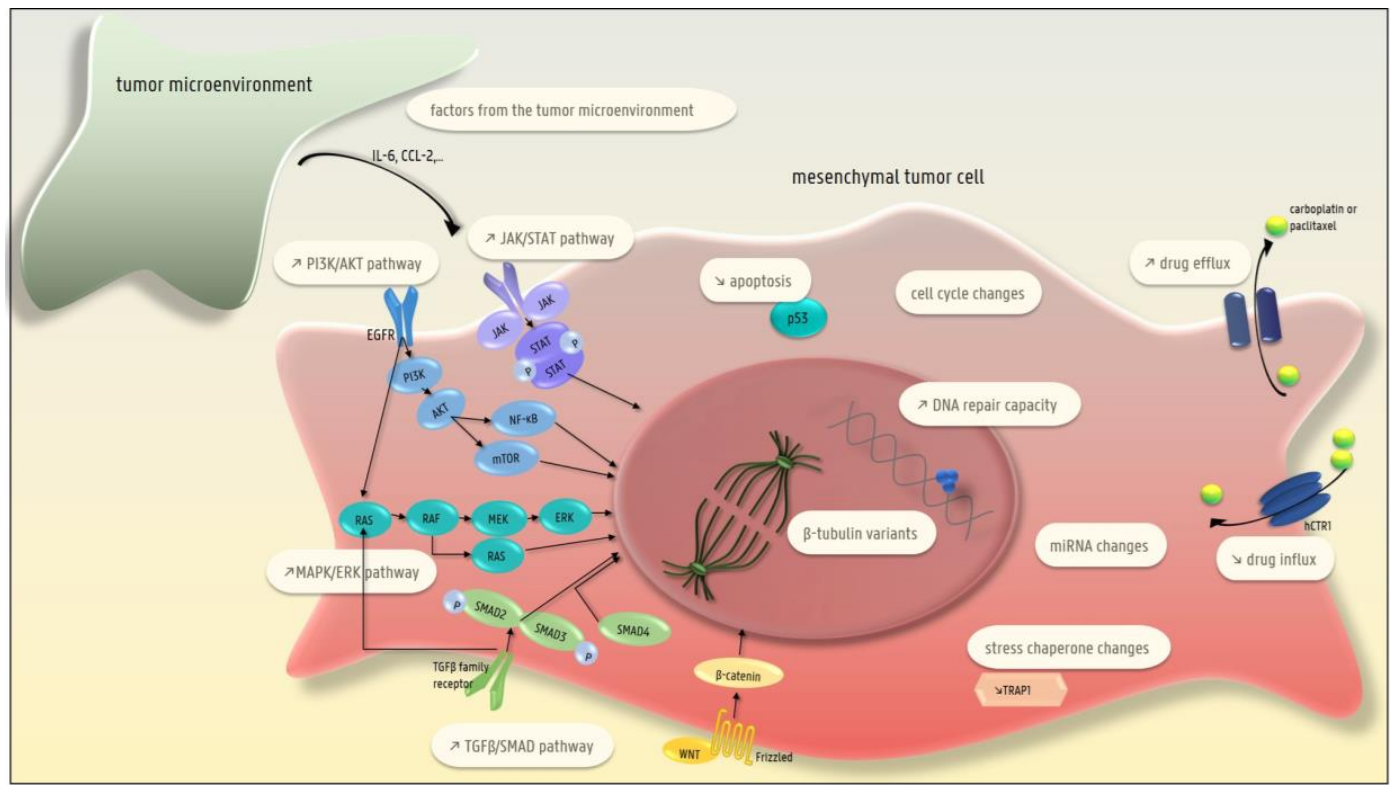

Figure 2. Different EMT-driven mechanisms leading to carboplatin and/or paclitaxel resistance in ovarian cancer cells: the presence of $\beta$-tubulin variants; lower drug uptake; higher drug efflux; increased DNA repair capacity; decreased apoptosis; changes in the cell cycle; changes in miRNA; and changes in different pathways (MAPK/ERK, TGF $\beta$-SMAD, JAK/STAT, PI3K-AKT-NFKB). In addition, factors secreted by the microenvironment can induce EMT-related therapy resistance.

\subsection{The Presence of $\beta$-Tubulin Variants (Taxane-Specific Resistance)}

Six isotypes of $\beta$-tubulin have been described, all of which display tissue-specific distribution patterns. Class III $\beta$-tubulin (TUBB3) is expressed during early neural differentiation and is normally not present in epithelial cells. Abnormal expression of TUBB3 in ovarian cancer cells induces instability and/or slower polymerization of microtubules which leads to paclitaxel resistance [84]. MiR-200c, a repressor of the EMT-transcription factors Zeb1 and Zeb2, interacted directly with TUBB3 transcripts thereby inhibiting translation. This explains how the miR-200c family can induce sensitivity to paclitaxel [85]. Moreover, short-term treatment of OVCA 433 and HEY ovarian cancer cell lines with paclitaxel promoted EMT and increased the expression of the more paclitaxel-resistant $\beta$-tubulin isotypes III and IV [29].

\subsection{Lower Drug Uptake}

Platinum agents enter cells primarily by active transport by the copper transporter 1 (CTR1) [86]. Recent evidence indicates a link between EMT and lower drug uptake. Indeed, more mesenchymal ovarian cancer cell lines that were platinum-resistant expressed lower levels of the copper transporter 1 (CTR1) than their platinum-sensitive and more epithelial counterparts [87]. In line with this, FOXM1 (a member of the forkhead transcription factor family) mediated platinum resistance in human embryonic kidney cells via activation of the WNT/ $\beta$-catenin pathway, which induces EMT, and inhibition of the human copper transporter 1 (hCTR1), which results in lower drug uptake [88].

\subsection{Higher Efflux of the Drug}

EMT transcription factors can induce the expression of ATP-binding cassette (ABC) transporters. These drug efflux pumps are associated with multidrug resistance, and their promoters contain different binding sites for EMT transcription factors. For example, Twist can directly bind to the E-box elements of $A B C$ transporters [89]. Indeed, P-glycoprotein, a well-known drug efflux pump, was expressed at higher levels in more mesenchymal and therapy-resistant ovarian cancer cell lines, than in more epithelial and chemo-sensitive cell lines [90]. In addition, nidogen-1 (NID-1), which induced EMT 
and platinum resistance in OVCAR3 and HEY cell lines by stimulating the ERK/MAPK pathway, was associated with upregulation of the drug efflux transporters MDR1 and ABCG2 [91]. The correlation between platinum-resistance, NID1 and stronger expression of MDR1 and ABCG2 was confirmed by whole transcriptome profiling on 28 HGS ovarian cancer tissues [92]. Another example is the sequestration of platinum agents (with consequent lower intracellular platinum concentrations) by the copper-transporting P-type ATPase pump, ATP7B. Downregulation of ATP7B expression by miR-15a and miR-16, two EMT-inhibitors, led to increased cisplatin sensitivity in vitro and in vivo $[93,94]$. Furthermore, in the mesenchymal OVCAR-8R cells, platinum resistance was mediated by sequestration of platinum by methallothioneins [81].

Furthermore, mounting evidence shows that EMT is a driver of stemness (reviewed in [62]). In analogy with normal stem cells, cancer stem cells protect themselves against chemical mutagens for example chemotherapy, by high expression levels of drug efflux pumps such as ATP-binding cassette transporters, resulting in therapy resistance. In line with this expression of Oct4A, a transcription factor that regulates self-renewal and pluripotency in embryonic stem cells, correlated with CSCs and promoted chemoresistance by upregulating cytoskeletal and extracellular matrix-associated proteins, as well as upregulating ATP-binding cassette sub-family E-member in several ovarian cancer cell lines $[62,95,96]$.

\subsection{Higher DNA Repair Capacity}

EMT can activate enhanced repair of carboplatin-induced DNA damage, counteracting the toxic effect of this chemotherapeutic agent. This is illustrated by sirtuin 6 (SIRT6), an NAD-dependent protein deacetylase, which induced $\beta$-catenin mediated EMT and increased DNA repair capacity by activating the DNA repair enzyme, poly ADP-ribose polymerase (PARP). Nuclear SIRT6 expression has been associated with platinum resistance and shorter overall survival in 75 serous ovarian cancer patients [97]. In addition, short-term treatment of OVCA 433 and HEY cell lines with platinum agents induced an EMT-phenotype and upregulated the DNA-excision repair protein ERCC1 (excision repair cross-complementation group 1) [29]. Finally, in an orthotopic ovarian cancer mouse model, miR-506 inhibited EMT and improved the response to cisplatin and olaparib by direct control of RAD51, a double-strand DNA repair gene [98].

\subsection{Decreased Apoptosis}

Snail and Slug induce chemoresistance by inhibiting p53-mediated apoptosis. Both transcription factors confer resistance to $\mathrm{p} 53$-mediated apoptosis by inhibiting different pro-apoptotic molecules, such as PUMA/BBC3, ATM, and PTEN [99]. On the other hand, both wild-type TP53 and PUMA are associated with sensitivity to platinum agents in ovarian cancer [100]. Furthermore, Snail exerts an anti-apoptotic effect by stimulating AKT activation (which inhibits p53-mediated apoptosis), slowing down cell-cycle continuation and increasing the expression of Bcl-XL, a pro-survival protein [101]. Indeed, endothelin (ET-1) induced Snail-mediated EMT and chemoresistance in EOC cell lines by activating the PI3-K/Akt pathway and inhibiting apoptosis via a bcl-2 dependent mechanism [102]. Moreover, platinum-resistant OVCAR-8 spheroids were more mesenchymal, and showed increased expression of the apoptosis inhibitors BIRC 3 and BCL2L1 compared to platinum sensitive OVCAR-8 spheroids [81].

\subsection{Changes in the MAPK/ERK Pathway}

The MAPK/ERK pathway (also known as the Ras-Raf-MEK-ERK pathway) is known to induce EMT and is also associated with platinum resistance $[15,19]$. This is exemplified by FOXC2, a member of the forkhead box (FOX) transcription family, which induced resistance to platinum-based chemotherapy in ovarian cancer cells by activating the AKT and MAPK pathways [103]. Another example is nidogen-1 (NID1), which promoted EMT and platinum resistance in OVCAR3 and HEY cells by stimulating the ERK/MAPK pathway [91]. Moreover, inhibiting ERK2 activation with a selective MEK inhibitor 
decreased platinum-induced EMT and platinum resistance in OVCA 433 cells [104]. In line with this, treating platinum-resistant SKOV3 cells with a MEK inhibitor inhibited ERK phosphorylation and EMT induction and decreased platinum resistance [105].

\subsection{Changes in EGFR Signaling}

The EGFR pathway is activated in more than $70 \%$ of ovarian cancer patients and its activation is correlated with platinum resistance and poor prognosis [106].

A link between EMT, EGFR signaling, and therapy resistance has been demonstrated by different authors [107-109]. A first example is that of TGF $\beta 1$, a potent EMT inducer, which induced the expression of the sialyltransferase ST3GAL. Sialylation of the EGFR by ST3GAL increased EGFR expression and activated EMT, which promoted paclitaxel resistance in vitro and in vivo [108]. In addition, pyruvate dehydrogenase kinase 1 (PDK1) led to EMT and platinum resistance through phosphorylation of EGFR. Erlotinib, an inhibitor of EGFR tyrosine kinase activity, reversed this PDK1-induced platinum resistance in vitro, and silencing PDK1 in vivo also decreased platinum resistance. The authors suggested that PDK1-mediated signaling between the Warburg effect and the EGFR pathway induced chemotherapy resistance [109]. Finally, amphiregulin (AREG), which is inhibited by miR-34c-5p, induced EMT, CSC-like features and resistance to docetaxel and carboplatin in vitro through activation of the AREG-EGFR-ERK pathway. The authors also showed an inverse correlation between AREG expression and overall survival in 65 ovarian cancer patients [107].

Despite the contribution of EGFR-mediated EMT to therapy resistance, a recent Cochrane meta-analysis demonstrated little or no survival benefit from anti-EGFR treatment in ovarian cancer patients [110].

\subsection{Changes in the TGF $\beta$-SMAD Pathway}

The TGF $\beta$ signaling pathway is a dominant driver of EMT [111]. Mounting evidence also links this pathway to therapy resistance. This is exemplified by SMAD3, which induces the transcription of serine-threonine tyrosine kinase 1 (STYK1) by directly binding to its promoter. This binding promoted EMT and resistance to paclitaxel, both in vitro and in vivo [112]. Apart from TGF $\beta$, other ligands can activate the TGF $\beta$ pathway, such as BMP9, a member of the TGF $\beta$ superfamily. BMP9 induced platinum resistance by activating EMT in HO8910 and SKOV3 cell lines [113]. Furthermore, tumor-derived TGF $\beta$ stimulated TGF $\beta$ secretion by mesothelial cells with subsequent phosphorylation of Smad 2 and induction of Zeb1. Indeed, Zeb1 expression was correlated with shorter overall survival in 40 primary EOC samples, and silencing Zeb1 restored sensitivity to paclitaxel in vitro and in vivo [114].

\subsection{Changes in the PI3-K/AKT/NF- $K B$ and JAK/STAT Pathways}

The PI3-AKT/AKT pathway is activated in 40\% of ovarian cancers, and this activation is correlated with a poor prognosis $[115,116]$. Growing evidence shows that EMT mediated by the PI-3K/AKT/NF-KBand JAK/STAT-pathways can induce chemotherapy resistance, as has been shown in the following publications. As mentioned previously, FOXC2 could mediate platinum resistance in ovarian cancer cells through activation of the AKT and MAPK pathways [103]. A second example is lysyl oxidase (LOX), an enzyme that catalyzes the formation of cross-links between collagen and elastin in the extracellular matrix. Nuclear expression of LOX was associated with increased chemotherapy resistance, shorter progression-free survival and shorter overall survival in 70 advanced HGS ovarian cancer patients. The authors suggested that LOX activated EMT by inducing SLUG and TWIST1 and caused chemotherapy resistance through activation of the PI3K/AKT pathway [117]. Finally, the hematopoietic PBX interacting protein (HPIP) induced EMT and cisplatin resistance by activating the PI3-K/AKT pathway in OAW42 ovarian cancer cells [118].

The importance of the JAK/STAT-pathway in EMT-mediated chemoresistance is illustrated by resistin, a macrophage-derived cytokine associated with obesity and insulin resistance. This cytokine induced platinum resistance, EMT, and stemness in vitro and in vivo by binding Toll-like receptor-4 
(TLR4), and by stimulating the NF-кB-STAT3 pathway [119]. Moreover, STAT3 expression was associated with platinum resistance in EOC cells [120].

\subsection{Changes in the Cell Cycle}

Changes in cyclins and cyclin-dependent kinases, which are key regulators of the cell cycle, can also influence the response to chemotherapy. EMT can induce chemoresistance by interfering with the cell cycle, as exemplified by the effects of sperm-associated antigen 9 (SPAG9). Downregulation of SPAG9 in A10- and SKOV-3 ovarian cancer cell lines increased their sensitivity to platinum-based chemotherapy via induction of MET transition and upregulation of the cyclin-dependent kinase inhibitor protein p21, leading to reduced proliferation and cell cycle arrest [121]. In line with this, reduced proliferation mediated by p21, which drives G1 growth arrest, led to resistance to taxanes in eight ovarian cancer cell lines that showed an EMT-signature. Indeed, it is well known that proliferating cells respond better than quiescent cells to taxanes [122].

Mutated TP53 induced Notch3 and subsequently the expression of cyclin G1 (CCNG1), thereby promoting EMT and cisplatin resistance. Conversely, silencing CCNG1 resulted in a more epithelial-like phenotype with weaker expression of $\mathrm{CDH} 2$, Snail and Slug, and increased sensitivity to cisplatin in HO8910 and A2780 ovarian cancer cell lines. Moreover, an inverse correlation has been shown between the expression of CCNG1 in HGSOC tissues on the one hand and overall survival and progression-free survival on the other [123].

\subsection{Changes in Micro-RNAs}

The role of micro-RNAs in ovarian cancer and their influence on chemoresistance has been reviewed in several recent papers [124-126]. Micro-RNAs can regulate EMT and chemotherapy resistance by interacting with different transcripts, leading to their degradation and consequently preventing their translation. Indeed, a recent paper described nine microRNAs associated with platinum resistance in ovarian cancer, three of which are direct EMT regulators: miR-152, miR-27b, and miR-496 [127].

The best-known EMT-repressing micro-RNA family is the miR-200 family. Cisplatin can directly bind to pre-miR-200b, thereby inhibiting its processing into mature miRNA. In breast cancer cells, decreased expression of miR-200b promoted EMT and subsequent cisplatin resistance by directly inhibiting Zeb1 and Zeb2 [128,129].

Another example is miR-1294, a micro-RNA that enhanced cisplatin sensitivity and induced MET in vitro by directly inhibiting the anti-apoptotic gene insulin-like growth factor 1 receptor (IGF1R), leading to decreased expression of mTOR, AKT, and ErbB. Indeed miR-1294 expression was lower in samples from patients with platinum-resistant ovarian cancer compared to samples from patients with platinum sensitive disease [130].

It has been suggested that miR-363 directly inhibits Snail-induced EMT and thereby ameliorates platinum resistance in vivo. Furthermore miR-363 expression was lower in patients with platinumresistant EOC compared to platinum sensitive patients [131].

MiR-186 expression suppressed Twist1-induced EMT, and increased sensitivity to platinum-based chemotherapy in vitro and in vivo. Lower miR-186 expression was correlated with therapy resistance and poor survival in serous ovarian cancer samples from patients with FIGO stage IIIC or IV [83].

Whereas the above-mentioned micro-RNAs suppress EMT and therapy resistance, some micro-RNAs such as miR-20a, do the opposite. Indeed, miR-20a induced EMT and cisplatin resistance in OVCAR3 cells [132]. Furthermore, overexpression of miR-181a induced EMT and paclitaxel resistance in SKOV3 cells through upregulation of P-glycoprotein [133]. In addition, miR-216a was shown to induce EMT in liver cancer [134] and was associated with platinum resistance in SKOV3 cells [135]. Moreover, cancer-associated fibroblasts and cancer-associated adipocytes can secrete exosomes containing miR-21, an EMT-inducing micro-RNA [136], which has been shown to induce paclitaxel resistance in OVCA432 and SKOV3 cells [137]. 


\subsection{Changes in Stress Chaperones}

Stress chaperones bind to client proteins to protect them against irreversible aggregation in response to oxidative, acid and heat stress [138]. Several findings point to a link between stress chaperones, EMT and chemoresistance. The chaperone tumor necrosis factor-associated protein 1 (TRAP1) induces oxidative phosphorylation, with subsequent secretion of cytokines and remodeling of gene expression. Reduced TRAP1 expression caused cisplatin resistance by reducing the inhibition of p70S6K, a kinase that induces Snail (with subsequent E-cadherin repression) and that is often activated in ovarian cancer [139-141]. Another example is mortalin, a stress chaperone that induces EMT in breast cancer cells [142]. Silencing mortalin in ovarian cancer cell lines increased platinum sensitivity [143].

\subsection{Factors Produced by the Tumor Microenvironment}

The tumor microenvironment consists of different types of fibroblasts such as cancer-associated fibroblasts (CAFs), as well as immune cells, endothelial cells, and tissue specific and bone marrow-derived mesenchymal stem cells secreting different growth factors and ECM components [144]. This tumor microenvironment can promote ovarian cancer progression and appears to be an attractive therapeutic target $[145,146]$. Moreover, it is known that the tumor microenvironment can contribute to chemoresistance (reviewed in $[147,148]$ ). Indeed, CAFs can promote EMT and therapy resistance in ovarian cancer by secreting IL-6, which activates the JAK/STAT pathway and induces C/EBP transcription factors $[149,150]$ (reviewed in [151]). Furthermore carcinoma-associated mesenchymal stem cells induced platinum resistance in EOC cells and in a mouse model, via a Hedgehog-BMP4 signaling loop [152]. In addition, adipose-derived mesenchymal stem cells induced platinum resistance in EOC cells, probably by decreasing intracellular platinum accumulation [153]. Another example is chemokine (C-C motif) ligand 2 (CCL2), which attracts monocytes and macrophages to the tumor microenvironment. The attracted cells are named tumor-associated macrophages (TAMs). Inhibiting mouse stromal CCL2, an inducer of chemotherapy resistance, increased the therapeutic effect of carboplatin-paclitaxel [154].

Together, these findings highlight the key role of the tumor microenvironment in the development of therapy resistance and point to novel therapeutic targets for ovarian cancers that are refractory to therapy.

\section{EMT and Immunotherapy Resistance}

Ovarian cancer is an immunogenic tumor and a strong intratumoral CD8 ${ }^{+}$T-cell infiltration has been associated with improved overall survival [155]. Multiple pre-clinical and clinical studies are currently evaluating the effect of different immunotherapeutic regimens on ovarian cancer patients [156,157]. Recent reports indicate that EMT can also drive resistance to immunotherapy in several types of cancer [158-161]. Cells that undergo EMT can upregulate programmed cell death-ligand 1 (PD-L1), which inhibits the cytotoxicity of T cells by binding to their programmed cell death protein 1 (PD-1) receptor [62]. In breast cancer cells, induction of PD-L1, which was suppressed by miR-200, might be caused indirectly by ZEB1, by decreasing miR-200 expression [160]. In breast cancer, PD-L1 expression was induced upon PI3/AKT-mediated EMT [162]. Furthermore, by secreting thrombospondin-1 (TSP-1), cells that have undergone EMT can promote the generation of regulatory $\mathrm{T}$ cells (T regs), which suppress the cytotoxic T cell function [62]. In gastric cancer cells, it was shown that PD-L1 expression was induced via the STAT3 and mTOR pathways [163], both of which are well-known EMT-activating pathways [164,165]. Notably, anti-VEGF treatment suppressed PD-L1 expression and EMT via decreased STAT3 phosphorylation in cisplatin resistant ovarian cancer cells. Moreover, anti-VEGF and anti-PD-L1 agents acted synergistically to reduce tumor growth in vivo, which might have been due to enhancement of the immunotherapy efficacy by the anti-EMT effect of the anti-VEGF treatment [166]. 


\section{EMT and Stemness}

Mounting evidence [29,30,32-36] points to a small subset of cells within the tumor (cancer stem cells, CSCs) that can initiate tumors and drive metastasis and resistance to therapy. The American Association for Cancer Research defines a cancer stem cell as a tumor cell that can self-renew and generate the different lineages of differentiated cells composing the tumor [95].

The origin of a cancer stem cell remains debatable but two putative theories have been recently proposed: a normal stem cell could become an "activated stem cell" because of tissue damage or inflammation, or a mature differentiated cell could acquire the capacity of self-renewal to become an activated stem cell [167]. In a next step, the activated stem cell transforms into a cancer stem cell through mutations leading to inactivation of tumor suppressor genes and/or activation of oncogenes [167]. In addition, EMT is known as a driver of stemness [62].

Different mechanisms are responsible for the therapy resistance of CSCs. Like normal stem cells, they protect themselves against chemical mutagens, for example chemotherapy, by expressing drug efflux pumps such as ATP-binding cassette transporters [168]. Furthermore, they are more resistant to DNA damage because they inherently have greater DNA repair capacities [167]. In addition they proliferate slowly and express higher levels of anti-apoptotic genes [62,95].

With regard to ovarian cancer, several authors have shown that EMT induces stem-cell like cells $[33,169]$ that are associated with therapy resistance $[32,35]$. For example, TGF $\beta 1$-induced EMT triggered splice isoform switching of CD44, with upregulation of the mesenchymal variant CD44s, which promoted CSC-like features [169]. Moreover, knock-down of Snail in OVCAR8 cells decreased the expression of CSC markers such as CD117, CD133, and Nanog, and increased sensitivity to platinum-based chemotherapy [32]. That the CSC-like population arises after only 3-5 days of chemotherapy, indicates that this population is probably already present in the chemonaive tumor and is selected by the chemotherapy [29].

Interestingly, it was recently reported that mechanical stress, e.g., shear stress due to intra-abdominal fluid flow, might influence the behavior of tumor cells. Shear stress induced the formation of CSCs (with upregulation of Oct-4, c-Kit, ABCG2, and P-glycoprotein) and resistance to cisplatin and paclitaxel in vitro, through downregulation of miR-199a-3p and subsequent activation of the PI3K/Akt pathway [170].

In summary, these findings point to cancer stem cells as drivers of therapy resistance in ovarian cancer. Therefore, successfully targeting these crucial cells might be pivotal for overcoming resistance to chemotherapy. The precise mechanisms by which CSCs evade current therapeutic agents need more research. However, the lack of reliable cell surface markers makes it difficult to enrich a pure CSC population.

\section{Targeting EMT in Ovarian Cancer}

The above-mentioned evidence indicates that EMT contributes to chemotherapy resistance and stemness in ovarian cancer, making it a potential target to tackle therapy resistance. Several authors have reported that anti-EMT therapies reverse therapy resistance in vitro or in vivo. One example is the potent TGF $\beta$ inhibitor, SB-431542, which increased carboplatin sensitivity [61]. Likewise, synthetic inhibitory antibodies to the type II TGF- $\beta$ receptor (TGFBR2), reversed EMT and improved the response to carboplatin and anti-tumor immunity in vivo (fewer Tregs and more cytotoxic immune cells in the tumors) [38]. Furthermore, treatment with siRNA targeting TWIST increased platinum sensitivity in vivo. This siRNA was delivered into the cells by using hyaluronic-acid conjugated mesoporous silica nanoparticles (MSN-Has), which specifically bind to CSCs via their native ligand CD44 [171]. Similarly, treating a preclinical orthotopic mouse model with nanoliposome-delivered miR-15a and miR-16 improved cisplatin sensitivity [94]. These nanoparticles passively concentrated at the tumor site due to the leaky vasculature, which has more space between the endothelial cells compared to normal blood vessels [172]. Furthermore, treating SKOV-3/DDP cell lines with PD98059, a MEK inhibitor, led to silencing of the ERK-pathway and EMT, making the cells more sensitive to cisplatin [105]. 
Another example is ginsenoside $\mathrm{Rb} 1$ and its metabolite compound $\mathrm{K}$, which sensitized ovarian cancer cells to cisplatin and paclitaxel by inhibiting Wnt/ $\beta$-catenin signaling and EMT both in vivo and in vitro. The effect on therapy resistance was mediated by inactivation of the drug efflux transporters ABCG2 and P-glycoprotein [173]. Indeed, ABCG2 and other ABC drug transporters are known transcriptional targets of the $\beta$-catenin/TCF pathway [174]. Finally, luteolin $\left(5,7,3^{\prime}, 4^{\prime}\right.$-tetrahydroxyflavone), a flavonoid in fruits and vegetables, sensitized ovarian cancer cell lines to paclitaxel by inhibiting phosphorylation of FAK/ERK which leads to decreased nuclear expression of p65 and subsequently reduced EMT [175].

\section{Controversy about the Role of EMT in Ovarian Cancer Progression and Therapy Resistance}

Despite the overwhelming evidence for the contribution of EMT to ovarian cancer progression and therapy resistance, several publications have stated the opposite. For instance, among 46 ovarian cancer cell lines classified as epithelial or mesenchymal based on a previously published expression signature [176], the epithelial cell lines were more platinum-resistant than the mesenchymal ones [177]. These contradictory results sometimes raise the question whether EMT truly causes ovarian cancer progression and therapy resistance. Several confusing results might be explained by the fact that some authors specifically investigated end-stage EMT with a full-blown mesenchymal phenotype. However, cancer cells in partial EMT-states are probably more important for cancer progression and therapy resistance, again indicating the importance of cell plasticity [18]. Another problem is that the expression of EMT transcription factors is often increased only transiently during specific steps of cancer progression, which makes it difficult to detect [26]. For instance, to form a macroscopic metastasis, the reverse process of MET is required and EMT transcription factors are often downregulated [63]. Finally, the leading EMT transcription factors (Zeb1, Zeb2, Snail, Slug, and Twist1) are all capable of inducing (a form of) EMT, but additionally have separate non-redundant functions that are tissueand context specific. In addition, they can influence each other's expression, resulting in a complex regulatory network [26]. All things considered, investigation of EMT is extremely complex. Obviously, a better understanding of how EMT influences ovarian cancer progression and therapy resistance warrants more research.

\section{Conclusions}

Since $80 \%$ of patients with ovarian cancer relapse within five years after the initial response to therapy, the major hurdle to improving their prognosis is preventing development of therapy resistance. Growing evidence shows that EMT induces chemotherapy resistance and stemness. Here, we reviewed different mechanisms that lead to EMT-induced chemotherapy resistance. Several authors report promising results with preclinical anti-EMT therapies. However, more research is needed to elucidate the mechanisms leading to EMT-induced therapy resistance before anti-EMT therapies can be effectively tested in clinical trials.

Author Contributions: Conceptualization, N.L. and G.B.; methodology, N.L.; writing-original draft, N.L., H.D., P.T. and G.B.; review and editing, N.L. and G.B.; visualization, N.L.; supervision, G.B.

Funding: The laboratory of G.B. is supported by the Fonds Wetenschappelijk Onderzoek (3G050217W), the Geconcerteerde Onderzoeksacties Ghent University (GOA-01GB1013W), Vlaamse Liga tegen Kanker (365U8914U) and the Stichting tegen Kanker (FAF-F/2016/814). Nele Loret received a PhD grant from Bijzonder Onderzoeksfonds UGent (01D39116).

Acknowledgments: We thank all lab members for active discussion and critical reading, and Amin Bredan for editing the manuscript.

Conflicts of Interest: The authors declare no conflict of interest. The funders had no role in study design, data collection, analyses, interpretation, manuscript writing, or the decision to publish the results. 


\section{References}

1. Ferlay, J.; Colombet, M.; Soerjomataram, I.; Mathers, C.; Parkin, D.M.; Pineros, M.; Znaor, A.; Bray, F. Estimating the global cancer incidence and mortality in 2018: GLOBOCAN sources and methods. Int. J. Cancer 2019, 144, 1941-1953. [CrossRef] [PubMed]

2. Allemani, C.; Weir, H.K.; Carreira, H.; Harewood, R.; Spika, D.; Wang, X.S.; Bannon, F.; Ahn, J.V.; Johnson, C.J.; Bonaventure, A.; et al. Global surveillance of cancer survival 1995-2009: Analysis of individual data for 25,676,887 patients from 279 population-based registries in 67 countries (CONCORD-2). Lancet 2015, 385, 977-1010. [CrossRef]

3. Mor, G.; Alvero, A. The duplicitous origin of ovarian cancer. Rambam Maimonides Med. J. 2013, 4, e0006. [CrossRef] [PubMed]

4. Oberaigner, W.; Minicozzi, P.; Bielska-Lasota, M.; Allemani, C.; de Angelis, R.; Mangone, L.; Sant, M.; Eurocare Working, G. Survival for ovarian cancer in Europe: The across-country variation did not shrink in the past decade. Acta Oncol. 2012, 51, 441-453. [CrossRef] [PubMed]

5. Vaughan, S.; Coward, J.I.; Bast, R.C., Jr.; Berchuck, A.; Berek, J.S.; Brenton, J.D.; Coukos, G.; Crum, C.C.; Drapkin, R.; Etemadmoghadam, D.; et al. Rethinking ovarian cancer: Recommendations for improving outcomes. Nat. Rev. Cancer 2011, 11,719-725. [CrossRef] [PubMed]

6. Kurman, R.J.; Carcangiu, M.L.; Herrington, C.S.; Young, R.H. WHO Classification of Tumours of Female Reproductive Organs, 4th ed.; WHO Press: Lyon, France, 2014.

7. Meinhold-Heerlein, I.; Fotopoulou, C.; Harter, P.; Kurzeder, C.; Mustea, A.; Wimberger, P.; Hauptmann, S.; Sehouli, J. The new WHO classification of ovarian, fallopian tube, and primary peritoneal cancer and its clinical implications. Arch. Gynecol. Obstet. 2016, 293, 695-700. [CrossRef] [PubMed]

8. Labidi-Galy, S.I.; Papp, E.; Hallberg, D.; Niknafs, N.; Adleff, V.; Noe, M.; Bhattacharya, R.; Novak, M.; Jones, S.; Phallen, J.; et al. High grade serous ovarian carcinomas originate in the fallopian tube. Nat. Commun. 2017, 8, 1093. [CrossRef]

9. Walker, J.L.; Powell, C.B.; Chen, L.M.; Carter, J.; Bae Jump, V.L.; Parker, L.P.; Borowsky, M.E.; Gibb, R.K. Society of Gynecologic Oncology recommendations for the prevention of ovarian cancer. Cancer 2015, 121, 2108-2120. [CrossRef] [PubMed]

10. Zeppernick, F.; Meinhold-Heerlein, I. The new FIGO staging system for ovarian, fallopian tube, and primary peritoneal cancer. Arch. Gynecol. Obstet. 2014, 290, 839-842. [CrossRef]

11. Cancer Genome Atlas Research, N. Integrated genomic analyses of ovarian carcinoma. Nature 2011, 474, 609-615. [CrossRef]

12. Kurman, R.J.; Shih Ie, M. Pathogenesis of ovarian cancer: Lessons from morphology and molecular biology and their clinical implications. Int. J. Gynecol. Pathol. Off. J. Int. Soc. Gynecol. Pathol. 2008, 27, 151-160. [CrossRef] [PubMed]

13. Rojas, V.; Hirshfield, K.M.; Ganesan, S.; Rodriguez-Rodriguez, L. Molecular Characterization of Epithelial Ovarian Cancer: Implications for Diagnosis and Treatment. Int. J. Mol. Sci. 2016, 17, 2113. [CrossRef] [PubMed]

14. Berek, J.S.; Kehoe, S.T.; Kumar, L.; Friedlander, M. Cancer of the ovary, fallopian tube, and peritoneum. Int. J. Gynaecol. Obstet. Off. Organ Int. Fed. Gynaecol. Obstet. 2018, 143 (Suppl. 2), 59-78. [CrossRef]

15. Dongre, A.; Weinberg, R.A. New insights into the mechanisms of epithelial-mesenchymal transition and implications for cancer. Nat. Rev. Mol. Cell Biol. 2019, 20, 69-84. [CrossRef] [PubMed]

16. Bierie, B.; Pierce, S.E.; Kroeger, C.; Stover, D.G.; Pattabiraman, D.R.; Thiru, P.; Liu Donaher, J.; Reinhardt, F.; Chaffer, C.L.; Keckesova, Z.; et al. Integrin-beta4 identifies cancer stem cell-enriched populations of partially mesenchymal carcinoma cells. Proc. Natl. Acad. Sci. USA 2017, 114, E2337-E2346. [CrossRef] [PubMed]

17. Chaffer, C.L.; San Juan, B.P.; Lim, E.; Weinberg, R.A. EMT, cell plasticity and metastasis. Cancer Metastasis Rev. 2016, 35, 645-654. [CrossRef]

18. Pastushenko, I.; Brisebarre, A.; Sifrim, A.; Fioramonti, M.; Revenco, T.; Boumahdi, S.; Van Keymeulen, A.; Brown, D.; Moers, V.; Lemaire, S.; et al. Identification of the tumour transition states occurring during EMT. Nature 2018, 556, 463-468. [CrossRef]

19. Brozovic, A. The relationship between platinum drug resistance and epithelial-mesenchymal transition. Arch. Toxicol. 2017, 91, 605-619. [CrossRef] 
20. Guadamillas, M.C.; Cerezo, A.; Del Pozo, M.A. Overcoming anoikis-Pathways to anchorage-independent growth in cancer. J. Cell Sci. 2011, 124, 3189-3197. [CrossRef]

21. De Craene, B.; Berx, G. Regulatory networks defining EMT during cancer initiation and progression. Nat. Rev. Cancer 2013, 13, 97-110. [CrossRef]

22. Goossens, S.; Vandamme, N.; Van Vlierberghe, P.; Berx, G. EMT transcription factors in cancer development re-evaluated: Beyond EMT and MET. Biochim. Biophys. Acta Rev. Cancer 2017, 1868, 584-591. [CrossRef] [PubMed]

23. Nieto, M.A. Context-specific roles of EMT programmes in cancer cell dissemination. Nat. Cell Biol. 2017, 19, 416-418. [CrossRef] [PubMed]

24. Nieto, M.A.; Huang, R.Y.; Jackson, R.A.; Thiery, J.P. Emt: 2016. Cell 2016, 166, 21-45. [CrossRef] [PubMed]

25. Puisieux, A.; Brabletz, T.; Caramel, J. Oncogenic roles of EMT-inducing transcription factors. Nat. Cell Biol. 2014, 16, 488-494. [CrossRef] [PubMed]

26. Stemmler, M.P.; Eccles, R.L.; Brabletz, S.; Brabletz, T. Non-redundant functions of EMT transcription factors. Nat. Cell Biol. 2019, 21, 102-112. [CrossRef] [PubMed]

27. Lamouille, S.; Xu, J.; Derynck, R. Molecular mechanisms of epithelial-mesenchymal transition. Nat. Rev. Mol. Cell Biol. 2014, 15, 178-196. [CrossRef] [PubMed]

28. Sanchez-Tillo, E.; Lazaro, A.; Torrent, R.; Cuatrecasas, M.; Vaquero, E.C.; Castells, A.; Engel, P.; Postigo, A. ZEB1 represses E-cadherin and induces an EMT by recruiting the SWI/SNF chromatin-remodeling protein BRG1. Oncogene 2010, 29, 3490-3500. [CrossRef]

29. Abubaker, K.; Latifi, A.; Luwor, R.; Nazaretian, S.; Zhu, H.; Quinn, M.A.; Thompson, E.W.; Findlay, J.K.; Ahmed, N. Short-term single treatment of chemotherapy results in the enrichment of ovarian cancer stem cell-like cells leading to an increased tumor burden. Mol. Cancer 2013, 12, 24. [CrossRef]

30. Alwosaibai, K.; Abedini, A.; Al-Hujaily, E.M.; Tang, Y.; Garson, K.; Collins, O.; Vanderhyden, B.C. PAX2 maintains the differentiation of mouse oviductal epithelium and inhibits the transition to a stem cell-like state. Oncotarget 2017, 8, 76881-76897. [CrossRef]

31. Bapat, S.A.; Mali, A.M.; Koppikar, C.B.; Kurrey, N.K. Stem and progenitor-like cells contribute to the aggressive behavior of human epithelial ovarian cancer. Cancer Res. 2005, 65, 3025-3029. [CrossRef]

32. Hojo, N.; Huisken, A.L.; Wang, H.; Chirshev, E.; Kim, N.S.; Nguyen, S.M.; Campos, H.; Glackin, C.A.; Ioffe, Y.J.; Unternaehrer, J.J. Snail knockdown reverses stemness and inhibits tumour growth in ovarian cancer. Sci. Rep. 2018, 8, 8704. [CrossRef] [PubMed]

33. Lupia, M.; Angiolini, F.; Bertalot, G.; Freddi, S.; Sachsenmeier, K.F.; Chisci, E.; Kutryb-Zajac, B.; Confalonieri, S.; Smolenski, R.T.; Giovannoni, R.; et al. CD73 Regulates Stemness and Epithelial-Mesenchymal Transition in Ovarian Cancer-Initiating Cells. Stem Cell Rep. 2018, 10, 1412-1425. [CrossRef] [PubMed]

34. Park, G.B.; Kim, D. TLR5/7-mediated PI3K activation triggers epithelial-mesenchymal transition of ovarian cancer cells through WAVE3-dependent mesothelin or OCT4/SOX2 expression. Oncol. Rep. 2017, 38, 3167-3176. [CrossRef] [PubMed]

35. Ricci, F.; Fratelli, M.; Guffanti, F.; Porcu, L.; Spriano, F.; Dell'Anna, T.; Fruscio, R.; Damia, G. Patient-derived ovarian cancer xenografts re-growing after a cisplatinum treatment are less responsive to a second drug re-challenge: A new experimental setting to study response to therapy. Oncotarget 2017, 8 , 7441-7451. [CrossRef] [PubMed]

36. Kenda Suster, N.; Smrkolj, S.; Virant-Klun, I. Putative stem cells and epithelial-mesenchymal transition revealed in sections of ovarian tumor in patients with serous ovarian carcinoma using immunohistochemistry for vimentin and pluripotency-related markers. J. Ovarian Res. 2017, 10, 11. [CrossRef] [PubMed]

37. Pattabiraman, D.R.; Weinberg, R.A. Tackling the cancer stem cells-What challenges do they pose? Nat. Rev. Drug Discov. 2014, 13, 497-512. [CrossRef] [PubMed]

38. Newsted, D.; Banerjee, S.; Watt, K.; Nersesian, S.; Truesdell, P.; Blazer, L.L.; Cardarelli, L.; Adams, J.J.; Sidhu, S.S.; Craig, A.W. Blockade of TGF-beta signaling with novel synthetic antibodies limits immune exclusion and improves chemotherapy response in metastatic ovarian cancer models. Oncoimmunology 2019, 8, e1539613. [CrossRef] [PubMed]

39. Antoniou, A.; Pharoah, P.D.; Narod, S.; Risch, H.A.; Eyfjord, J.E.; Hopper, J.L.; Loman, N.; Olsson, H.; Johannsson, O.; Borg, A.; et al. Average risks of breast and ovarian cancer associated with BRCA1 or BRCA2 mutations detected in case Series unselected for family history: A combined analysis of 22 studies. Am. J. Hum. Genet. 2003, 72, 1117-1130. [CrossRef] [PubMed] 
40. King, M.C.; Marks, J.H.; Mandell, J.B.; The New York Breast Cancer Study Group. Breast and ovarian cancer risks due to inherited mutations in BRCA1 and BRCA2. Science 2003, 302, 643-646. [CrossRef]

41. Sengodan, S.K.; Sreelatha, K.H.; Nadhan, R.; Srinivas, P. Regulation of epithelial to mesenchymal transition by BRCA1 in breast cancer. Crit. Rev. Oncol./Hematol. 2018, 123, 74-82. [CrossRef]

42. Lakhani, S.R.; Manek, S.; Penault-Llorca, F.; Flanagan, A.; Arnout, L.; Merrett, S.; McGuffog, L.; Steele, D.; Devilee, P.; Klijn, J.G.; et al. Pathology of ovarian cancers in BRCA1 and BRCA2 carriers. Clin. Cancer Res. Off. J. Am. Assoc. Cancer Res. 2004, 10, 2473-2481. [CrossRef]

43. Wang, H.; Bierie, B.; Li, A.G.; Pathania, S.; Toomire, K.; Dimitrov, S.D.; Liu, B.; Gelman, R.; Giobbie-Hurder, A.; Feunteun, J.; et al. BRCA1/FANCD2/BRG1-Driven DNA Repair Stabilizes the Differentiation State of Human Mammary Epithelial Cells. Mol. Cell 2016, 63, 277-292. [CrossRef] [PubMed]

44. Huen, M.S.; Sy, S.M.; Chen, J. BRCA1 and its toolbox for the maintenance of genome integrity. Nat. Rev. Mol. Cell Biol. 2010, 11, 138-148. [CrossRef] [PubMed]

45. Sinha, A.; Paul, B.T.; Sullivan, L.M.; Sims, H.; El Bastawisy, A.; Yousef, H.F.; Zekri, A.N.; Bahnassy, A.A.; ElShamy, W.M. BRCA1-IRIS overexpression promotes and maintains the tumor initiating phenotype: Implications for triple negative breast cancer early lesions. Oncotarget 2017, 8, 10114-10135. [CrossRef] [PubMed]

46. Figueras, A.; Alsina-Sanchis, E.; Lahiguera, A.; Abreu, M.; Muinelo-Romay, L.; Moreno-Bueno, G.; Casanovas, O.; Graupera, M.; Matias-Guiu, X.; Vidal, A.; et al. A Role for CXCR4 in Peritoneal and Hematogenous Ovarian Cancer Dissemination. Mol. Cancer Ther. 2018, 17, 532-543. [CrossRef] [PubMed]

47. Klymenko, Y.; Kim, O.; Stack, M.S. Complex Determinants of Epithelial: Mesenchymal Phenotypic Plasticity in Ovarian Cancer. Cancers 2017, 9, 104. [CrossRef] [PubMed]

48. Sawada, K.; Mitra, A.K.; Radjabi, A.R.; Bhaskar, V.; Kistner, E.O.; Tretiakova, M.; Jagadeeswaran, S.; Montag, A.; Becker, A.; Kenny, H.A.; et al. Loss of E-cadherin promotes ovarian cancer metastasis via alpha 5-integrin, which is a therapeutic target. Cancer Res. 2008, 68, 2329-2339. [CrossRef]

49. Tone, A.A. Taking the Tube: From Normal Fallopian Tube Epithelium to Ovarian High-grade Serous Carcinoma. Clin. Obstet. Gynecol. 2017, 60, 697-710. [CrossRef]

50. Perets, R.; Wyant, G.A.; Muto, K.W.; Bijron, J.G.; Poole, B.B.; Chin, K.T.; Chen, J.Y.; Ohman, A.W.; Stepule, C.D.; Kwak, S.; et al. Transformation of the fallopian tube secretory epithelium leads to high-grade serous ovarian cancer in Brca;Tp53;Pten models. Cancer Cell 2013, 24, 751-765. [CrossRef]

51. Dean, M.; Davis, D.A.; Burdette, J.E. Activin A stimulates migration of the fallopian tube epithelium, an origin of high-grade serous ovarian cancer, through non-canonical signaling. Cancer Lett. 2017, 391, 114-124. [CrossRef]

52. Tan, D.S.; Agarwal, R.; Kaye, S.B. Mechanisms of transcoelomic metastasis in ovarian cancer. Lancet Oncol. 2006, 7, 925-934. [CrossRef]

53. Al Habyan, S.; Kalos, C.; Szymborski, J.; McCaffrey, L. Multicellular detachment generates metastatic spheroids during intra-abdominal dissemination in epithelial ovarian cancer. Oncogene 2018, 37, 5127-5135. [CrossRef] [PubMed]

54. Rizvi, I.; Gurkan, U.A.; Tasoglu, S.; Alagic, N.; Celli, J.P.; Mensah, L.B.; Mai, Z.; Demirci, U.; Hasan, T. Flow induces epithelial-mesenchymal transition, cellular heterogeneity and biomarker modulation in 3D ovarian cancer nodules. Proc. Natl. Acad. Sci. USA 2013, 110, E1974-E1983. [CrossRef] [PubMed]

55. Frisch, S.M.; Schaller, M.; Cieply, B. Mechanisms that link the oncogenic epithelial-mesenchymal transition to suppression of anoikis. J. Cell Sci. 2013, 126, 21-29. [CrossRef] [PubMed]

56. Liu, C.; Yang, F. Akt2/ZEB2 may be a biomarker for exfoliant cells in ascitic fluid in advanced grades of serous ovarian carcinoma. Tumour Biol. 2015, 36, 7213-7219. [CrossRef] [PubMed]

57. Veatch, A.L.; Carson, L.F.; Ramakrishnan, S. Differential expression of the cell-cell adhesion molecule E-cadherin in ascites and solid human ovarian tumor cells. Int. J. Cancer 1994, 58, 393-399. [CrossRef] [PubMed]

58. Burleson, K.M.; Hansen, L.K.; Skubitz, A.P. Ovarian carcinoma spheroids disaggregate on type I collagen and invade live human mesothelial cell monolayers. Clin. Exp. Metastasis 2004, 21, 685-697. [CrossRef] [PubMed]

59. Rosso, M.; Majem, B.; Devis, L.; Lapyckyj, L.; Besso, M.J.; Llaurado, M.; Abascal, M.F.; Matos, M.L.; Lanau, L.; Castellvi, J.; et al. E-cadherin: A determinant molecule associated with ovarian cancer progression, dissemination and aggressiveness. PLOS ONE 2017, 12. [CrossRef] 
60. Ocana, O.H.; Corcoles, R.; Fabra, A.; Moreno-Bueno, G.; Acloque, H.; Vega, S.; Barrallo-Gimeno, A.; Cano, A.; Nieto, M.A. Metastatic colonization requires the repression of the epithelial-mesenchymal transition inducer Prrx1. Cancer Cell 2012, 22, 709-724. [CrossRef]

61. Rafehi, S.; Ramos, Y.V.; Bertrand, M.; McGee, J.; Prefontaine, M.; Sugimoto, A.; DiMattia, G.E.; Shepherd, T.G. TGF $\beta$ signaling regulates epithelial-mesenchymal plasticity in ovarian cancer ascites-derived spheroids. Endocr-Relat Cancer 2016, 23, 147-159. [CrossRef]

62. Shibue, T.; Weinberg, R.A. EMT, CSCs, and drug resistance: The mechanistic link and clinical implications. Nat. Rev. Clin. Oncol. 2017, 14, 611-629. [CrossRef] [PubMed]

63. Brabletz, T. To differentiate or not-Routes towards metastasis. Nat. Rev. Cancer 2012, 12, 425-436. [CrossRef] [PubMed]

64. Koensgen, D.; Freitag, C.; Klaman, I.; Dahl, E.; Mustea, A.; Chekerov, R.; Braicu, I.; Lichtenegger, W.; Sehouli, J. Expression and localization of e-cadherin in epithelial ovarian cancer. AntiCancer Res. 2010, 30, 2525-2530. [PubMed]

65. Pradeep, S.; Kim, S.W.; Wu, S.Y.; Nishimura, M.; Chaluvally-Raghavan, P.; Miyake, T.; Pecot, C.V.; Kim, S.J.; Choi, H.J.; Bischoff, F.Z.; et al. Hematogenous metastasis of ovarian cancer: Rethinking mode of spread. Cancer Cell 2014, 26, 77-91. [CrossRef] [PubMed]

66. Strauss, R.; Li, Z.Y.; Liu, Y.; Beyer, I.; Persson, J.; Sova, P.; Moller, T.; Pesonen, S.; Hemminki, A.; Hamerlik, P.; et al. Analysis of epithelial and mesenchymal markers in ovarian cancer reveals phenotypic heterogeneity and plasticity. PLOS ONE 2011, 6, e16186. [CrossRef]

67. Klymenko, Y.; Johnson, J.; Bos, B.; Lombard, R.; Campbell, L.; Loughran, E.; Stack, M.S. Heterogeneous Cadherin Expression and Multicellular Aggregate Dynamics in Ovarian Cancer Dissemination. Neoplasia 2017, 19, 549-563. [CrossRef] [PubMed]

68. Huang, R.Y.; Wong, M.K.; Tan, T.Z.; Kuay, K.T.; Ng, A.H.; Chung, V.Y.; Chu, Y.S.; Matsumura, N.; Lai, H.C.; Lee, Y.F.; et al. An EMT spectrum defines an anoikis-resistant and spheroidogenic intermediate mesenchymal state that is sensitive to e-cadherin restoration by a src-kinase inhibitor, saracatinib (AZD0530). Cell Death Dis. 2013, 4, e915. [CrossRef] [PubMed]

69. Hudson, L.G.; Zeineldin, R.; Stack, M.S. Phenotypic plasticity of neoplastic ovarian epithelium: Unique cadherin profiles in tumor progression. Clin. Exp. Metastasis 2008, 25, 643-655. [CrossRef] [PubMed]

70. Vang, R.; Shih Ie, M.; Kurman, R.J. Ovarian low-grade and high-grade serous carcinoma: Pathogenesis, clinicopathologic and molecular biologic features, and diagnostic problems. Adv. Anat. Pathol. 2009, 16, 267-282. [CrossRef]

71. Sadlecki, P.; Grabiec, M.; Grzanka, D.; Jozwicki, J.; Antosik, P.; Walentowicz-Sadlecka, M. Expression of zinc finger transcription factors (ZNF143 and ZNF281) in serous borderline ovarian tumors and low-grade ovarian cancers. J. Ovarian Res. 2019, 12, 23. [CrossRef]

72. Sadlecki, P.; Jozwicki, J.; Antosik, P.; Grabiec, M. Expression of selected epithelial-mesenchymal transition transcription factors in serous borderline ovarian tumors and type I ovarian cancers. Tumour Biol. 2018, 40, 1010428318784807. [CrossRef] [PubMed]

73. Salamanca, C.M.; Maines-Bandiera, S.L.; Leung, P.C.; Hu, Y.L.; Auersperg, N. Effects of epidermal growth factor/hydrocortisone on the growth and differentiation of human ovarian surface epithelium. J. Soc. Gynecol. Investig. 2004, 11, 241-251. [CrossRef] [PubMed]

74. Cheng, J.C.; Auersperg, N.; Leung, P.C. Inhibition of p53 induces invasion of serous borderline ovarian tumor cells by accentuating PI3K/Akt-mediated suppression of E-cadherin. Oncogene 2011, 30, 1020-1031. [CrossRef] [PubMed]

75. Thomas, J.P.; Lautermann, J.; Liedert, B.; Seiler, F.; Thomale, J. High accumulation of platinum-DNA adducts in strial marginal cells of the cochlea is an early event in cisplatin but not carboplatin ototoxicity. Mol. Pharmacol. 2006, 70, 23-29. [CrossRef] [PubMed]

76. Judson, P.L.; Watson, J.M.; Gehrig, P.A.; Fowler, W.C., Jr.; Haskill, J.S. Cisplatin inhibits paclitaxel-induced apoptosis in cisplatin-resistant ovarian cancer cell lines: Possible explanation for failure of combination therapy. Cancer Res. 1999, 59, 2425-2432. [PubMed]

77. Siddik, Z.H. Cisplatin: Mode of cytotoxic action and molecular basis of resistance. Oncogene 2003, 22, 7265-7279. [CrossRef] [PubMed]

78. Rowinsky, E.K.; Donehower, R.C. Paclitaxel (taxol). N. Engl. J. Med. 1995, 332, 1004-1014. [CrossRef] [PubMed] 
79. Baribeau, S.; Chaudhry, P.; Parent, S.; Asselin, E. Resveratrol inhibits cisplatin-induced epithelial-to-mesenchymal transition in ovarian cancer cell lines. PLoS ONE 2014, 9, e86987. [CrossRef]

80. Brozovic, A.; Duran, G.E.; Wang, Y.C.; Francisco, E.B.; Sikic, B.I. The miR-200 family differentially regulates sensitivity to paclitaxel and carboplatin in human ovarian carcinoma OVCAR-3 and MES-OV cells. Mol. Oncol. 2015, 9, 1678-1693. [CrossRef]

81. Chowanadisai, W.; Messerli, S.M.; Miller, D.H.; Medina, J.E.; Hamilton, J.W.; Messerli, M.A.; Brodsky, A.S. Cisplatin Resistant Spheroids Model Clinically Relevant Survival Mechanisms in Ovarian Tumors. PLoS ONE 2016, 11, e0151089. [CrossRef]

82. Haslehurst, A.M.; Koti, M.; Dharsee, M.; Nuin, P.; Evans, K.; Geraci, J.; Childs, T.; Chen, J.; Li, J.; Weberpals, J.; et al. EMT transcription factors snail and slug directly contribute to cisplatin resistance in ovarian cancer. BMC Cancer 2012, 12, 91. [CrossRef] [PubMed]

83. Zhu, X.; Shen, H.; Yin, X.; Long, L.; Xie, C.; Liu, Y.; Hui, L.; Lin, X.; Fang, Y.; Cao, Y.; et al. miR-186 regulation of Twist1 and ovarian cancer sensitivity to cisplatin. Oncogene 2016, 35, 323-332. [CrossRef] [PubMed]

84. Izutsu, N.; Maesawa, C.; Shibazaki, M.; Oikawa, H.; Shoji, T.; Sugiyama, T.; Masuda, T. Epigenetic modification is involved in aberrant expression of class III beta-tubulin, TUBB3, in ovarian cancer cells. Int. J. Oncol. 2008, 32, 1227-1235. [PubMed]

85. Cochrane, D.R.; Howe, E.N.; Spoelstra, N.S.; Richer, J.K. Loss of miR-200c: A Marker of Aggressiveness and Chemoresistance in Female Reproductive Cancers. J. Oncol. 2010, 2010, 821717. [CrossRef] [PubMed]

86. Galluzzi, L.; Vitale, I.; Michels, J.; Brenner, C.; Szabadkai, G.; Harel-Bellan, A.; Castedo, M.; Kroemer, G. Systems biology of cisplatin resistance: Past, present and future. Cell Death Dis. 2014, 5, e1257. [CrossRef] [PubMed]

87. Sonego, M.; Pellizzari, I.; Dall'Acqua, A.; Pivetta, E.; Lorenzon, I.; Benevol, S.; Bomben, R.; Spessotto, P.; Sorio, R.; Gattei, V.; et al. Common biological phenotypes characterize the acquisition of platinum-resistance in epithelial ovarian cancer cells. Sci. Rep. 2017, 7, 7104. [CrossRef] [PubMed]

88. Chiu, W.T.; Huang, Y.F.; Tsai, H.Y.; Chen, C.C.; Chang, C.H.; Huang, S.C.; Hsu, K.F.; Chou, C.Y. FOXM1 confers to epithelial-mesenchymal transition, stemness and chemoresistance in epithelial ovarian carcinoma cells. Oncotarget 2015, 6, 2349-2365. [CrossRef]

89. Saxena, M.; Stephens, M.A.; Pathak, H.; Rangarajan, A. Transcription factors that mediate epithelial-mesenchymal transition lead to multidrug resistance by upregulating $A B C$ transporters. Cell Death Dis. 2011, 2, e179. [CrossRef]

90. Feng, T.; Wang, Y.; Lang, Y.; Zhang, Y. KDM5A promotes proliferation and EMT in ovarian cancer and closely correlates with PTX resistance. Mol. Med. Rep. 2017, 16, 3573-3580. [CrossRef]

91. Zhang, Y.; Huang, S.; Guo, Y.; Li, L. MiR-1294 confers cisplatin resistance in ovarian Cancer cells by targeting IGF1R. Biomed. Pharmacother. Biomed. Pharmacother. 2018, 106, 1357-1363. [CrossRef]

92. Zhou, Y.; Zhu, Y.; Fan, X.; Zhang, C.; Wang, Y.; Zhang, L.; Zhang, H.; Wen, T.; Zhang, K.; Huo, X.; et al. NID1, a new regulator of EMT required for metastasis and chemoresistance of ovarian cancer cells. Oncotarget 2017, 8, 33110-33121. [CrossRef] [PubMed]

93. Koti, M.; Gooding, R.J.; Nuin, P.; Haslehurst, A.; Crane, C.; Weberpals, J.; Childs, T.; Bryson, P.; Dharsee, M.; Evans, K.; et al. Identification of the IGF1/PI3K/NF kappaB/ERK gene signalling networks associated with chemotherapy resistance and treatment response in high-grade serous epithelial ovarian cancer. BMC Cancer 2013, 13, 549. [CrossRef] [PubMed]

94. Dmitriev, O.Y. Mechanism of tumor resistance to cisplatin mediated by the copper transporter ATP7B. Biochem. Cell Biol. Biochim. Biol. Cell. 2011, 89, 138-147. [CrossRef] [PubMed]

95. Dwivedi, S.K.; Mustafi, S.B.; Mangala, L.S.; Jiang, D.; Pradeep, S.; Rodriguez-Aguayo, C.; Ling, H.; Ivan, C.; Mukherjee, P.; Calin, G.A.; et al. Therapeutic evaluation of microRNA-15a and microRNA-16 in ovarian cancer. Oncotarget 2016, 7, 15093-15104. [CrossRef] [PubMed]

96. Clarke, M.F.; Dick, J.E.; Dirks, P.B.; Eaves, C.J.; Jamieson, C.H.; Jones, D.L.; Visvader, J.; Weissman, I.L.; Wahl, G.M. Cancer stem cells-Perspectives on current status and future directions: AACR Workshop on cancer stem cells. Cancer Res. 2006, 66, 9339-9344. [CrossRef]

97. Samardzija, C.; Greening, D.W.; Escalona, R.; Chen, M.; Bilandzic, M.; Luwor, R.; Kannourakis, G.; Findlay, J.K.; Ahmed, N. Knockdown of stem cell regulator Oct4A in ovarian cancer reveals cellular reprogramming associated with key regulators of cytoskeleton-extracellular matrix remodelling. Sci. Rep. 2017, 7, 46312. [CrossRef] [PubMed] 
98. Bae, J.S.; Noh, S.J.; Kim, K.M.; Park, S.H.; Hussein, U.K.; Park, H.S.; Park, B.H.; Ha, S.H.; Lee, H.; Chung, M.J.; et al. SIRT6 Is Involved in the Progression of Ovarian Carcinomas via beta-Catenin-Mediated Epithelial to Mesenchymal Transition. Front. Oncol. 2018, 8, 538. [CrossRef]

99. Liu, G.; Yang, D.; Rupaimoole, R.; Pecot, C.V.; Sun, Y.; Mangala, L.S.; Li, X.; Ji, P.; Cogdell, D.; Hu, L.; et al. Augmentation of response to chemotherapy by microRNA-506 through regulation of RAD51 in serous ovarian cancers. J. Natl. Cancer Inst. 2015, 107. [CrossRef]

100. Kurrey, N.K.; Jalgaonkar, S.P.; Joglekar, A.V.; Ghanate, A.D.; Chaskar, P.D.; Doiphode, R.Y.; Bapat, S.A. Snail and slug mediate radioresistance and chemoresistance by antagonizing p53-mediated apoptosis and acquiring a stem-like phenotype in ovarian cancer cells. Stem Cells 2009, 27, 2059-2068. [CrossRef]

101. Fraser, M.; Bai, T.; Tsang, B.K. Akt promotes cisplatin resistance in human ovarian cancer cells through inhibition of p53 phosphorylation and nuclear function. Int. J. Cancer 2008, 122, 534-546. [CrossRef]

102. Vega, S.; Morales, A.V.; Ocana, O.H.; Valdes, F.; Fabregat, I.; Nieto, M.A. Snail blocks the cell cycle and confers resistance to cell death. Genes Dev. 2004, 18, 1131-1143. [CrossRef] [PubMed]

103. Rosano, L.; Cianfrocca, R.; Spinella, F.; Di Castro, V.; Nicotra, M.R.; Lucidi, A.; Ferrandina, G.; Natali, P.G.; Bagnato, A. Acquisition of chemoresistance and EMT phenotype is linked with activation of the endothelin A receptor pathway in ovarian carcinoma cells. Clin. Cancer Res. Off. J. Am. Assoc. Cancer Res. 2011, 17, 2350-2360. [CrossRef] [PubMed]

104. Li, C.; Ding, H.; Tian, J.; Wu, L.; Wang, Y.; Xing, Y.; Chen, M. Forkhead Box Protein C2 (FOXC2) Promotes the Resistance of Human Ovarian Cancer Cells to Cisplatin In Vitro and In Vivo. Cell. Physiol. Biochem. Int. J. Exp. Cell. Physiol. Biochem. Pharmacol. 2016, 39, 242-252. [CrossRef] [PubMed]

105. Latifi, A.; Abubaker, K.; Castrechini, N.; Ward, A.C.; Liongue, C.; Dobill, F.; Kumar, J.; Thompson, E.W.; Quinn, M.A.; Findlay, J.K.; et al. Cisplatin treatment of primary and metastatic epithelial ovarian carcinomas generates residual cells with mesenchymal stem cell-like profile. J. Cell. Biochem. 2011, 112, 2850-2864. [CrossRef] [PubMed]

106. Hou, L.; Hou, X.; Wang, L.; Li, Z.; Xin, B.; Chen, J.; Gao, X.; Mu, H. PD98059 impairs the cisplatin-resistance of ovarian cancer cells by suppressing ERK pathway and epithelial mesenchymal transition process. Cancer Biomark. Sect. A Dis. Markers 2017, 21, 187-194. [CrossRef] [PubMed]

107. Granados, M.L.; Hudson, L.G.; Samudio-Ruiz, S.L. Contributions of the Epidermal Growth Factor Receptor to Acquisition of Platinum Resistance in Ovarian Cancer Cells. PLoS ONE 2015, 10, e0136893. [CrossRef] [PubMed]

108. Tung, S.L.; Huang, W.C.; Hsu, F.C.; Yang, Z.P.; Jang, T.H.; Chang, J.W.; Chuang, C.M.; Lai, C.R.; Wang, L.H. miRNA-34c-5p inhibits amphiregulin-induced ovarian cancer stemness and drug resistance via downregulation of the AREG-EGFR-ERK pathway. Oncogenesis 2017, 6, e326. [CrossRef] [PubMed]

109. Wu, X.; Zhao, J.; Ruan, Y.; Sun, L.; Xu, C.; Jiang, H. Sialyltransferase ST3GAL1 promotes cell migration, invasion, and TGF-beta1-induced EMT and confers paclitaxel resistance in ovarian cancer. Cell Death Dis. 2018, 9, 1102. [CrossRef] [PubMed]

110. Zhang, M.; Cong, Q.; Zhang, X.Y.; Zhang, M.X.; Lu, Y.Y.; Xu, C.J. Pyruvate dehydrogenase kinase 1 contributes to cisplatin resistance of ovarian cancer through EGFR activation. J. Cell. Physiol. 2019, 234, 6361-6370. [CrossRef]

111. Morrison, J.; Thoma, C.; Goodall, R.J.; Lyons, T.J.; Gaitskell, K.; Wiggans, A.J.; Bryant, A. Epidermal growth factor receptor blockers for the treatment of ovarian cancer. Cochrane Database Syst. Rev. 2018, 10, CD007927. [CrossRef]

112. Xu, J.; Lamouille, S.; Derynck, R. TGF-beta-induced epithelial to mesenchymal transition. Cell Res. 2009, 19, 156-172. [CrossRef] [PubMed]

113. Shi, Y.; Zhang, J.; Liu, M.; Huang, Y.; Yin, L. SMAD3 inducing the transcription of STYK1 to promote the EMT process and improve the tolerance of ovarian carcinoma cells to paclitaxel. J. Cell. Biochem. 2019. [CrossRef] [PubMed]

114. Wang, Y.; Yang, B.; Zhao, J.; Yu, X.; Liu, X.; Zhang, L.; Zhang, Y.; Li, X.; Zhai, Z. Epithelialmesenchymal transition induced by bone morphogenetic protein 9 hinders cisplatin efficacy in ovarian cancer cells. Mol. Med. Rep. 2019, 19, 1501-1508. [CrossRef] [PubMed]

115. Sakata, J.; Utsumi, F.; Suzuki, S.; Niimi, K.; Yamamoto, E.; Shibata, K.; Senga, T.; Kikkawa, F.; Kajiyama, H. Inhibition of ZEB1 leads to inversion of metastatic characteristics and restoration of paclitaxel sensitivity of chronic chemoresistant ovarian carcinoma cells. Oncotarget 2017, 8, 99482-99494. [CrossRef] [PubMed] 
116. Altomare, D.A.; Wang, H.Q.; Skele, K.L.; De Rienzo, A.; Klein-Szanto, A.J.; Godwin, A.K.; Testa, J.R. AKT and mTOR phosphorylation is frequently detected in ovarian cancer and can be targeted to disrupt ovarian tumor cell growth. Oncogene 2004, 23, 5853-5857. [CrossRef] [PubMed]

117. Shayesteh, L.; Lu, Y.; Kuo, W.L.; Baldocchi, R.; Godfrey, T.; Collins, C.; Pinkel, D.; Powell, B.; Mills, G.B.; Gray, J.W. PIK3CA is implicated as an oncogene in ovarian cancer. Nat. Genet. 1999, 21, 99-102. [CrossRef] [PubMed]

118. De Donato, M.; Petrillo, M.; Martinelli, E.; Filippetti, F.; Zannoni, G.F.; Scambia, G.; Gallo, D. Uncovering the role of nuclear Lysyl oxidase (LOX) in advanced high grade serous ovarian cancer. Gynecol. Oncol. 2017, 146, 170-178. [CrossRef] [PubMed]

119. Bugide, S.; Gonugunta, V.K.; Penugurti, V.; Malisetty, V.L.; Vadlamudi, R.K.; Manavathi, B. HPIP promotes epithelial-mesenchymal transition and cisplatin resistance in ovarian cancer cells through PI3K/AKT pathway activation. Cell. Oncol. 2017, 40, 133-144. [CrossRef] [PubMed]

120. Qiu, L.; Zhang, G.F.; Yu, L.; Wang, H.Y.; Jia, X.J.; Wang, T.J. Novel oncogenic and chemoresistance-inducing functions of resistin in ovarian cancer cells require miRNAs-mediated induction of epithelial-to-mesenchymal transition. Sci. Rep. 2018, 8, 12522. [CrossRef] [PubMed]

121. Sheng, W.J.; Jiang, H.; Wu, D.L.; Zheng, J.H. Early responses of the STAT3 pathway to platinum drugs are associated with cisplatin resistance in epithelial ovarian cancer. Braz. J. Med. Biol. Res. Rev. Bras. Pesqui. Med. Biol. 2013, 46, 650-658. [CrossRef]

122. Jagadish, N.; Fatima, R.; Sharma, A.; Devi, S.; Suri, V.; Kumar, V.; Suri, A. Sperm associated antigen 9 (SPAG9) a promising therapeutic target of ovarian carcinoma. Tumour Biol. 2018, 40, 1010428318773652. [CrossRef] [PubMed]

123. Duran, G.E.; Wang, Y.C.; Moisan, F.; Francisco, E.B.; Sikic, B.I. Decreased levels of baseline and drug-induced tubulin polymerisation are hallmarks of resistance to taxanes in ovarian cancer cells and are associated with epithelial-to-mesenchymal transition. Br. J. Cancer 2017, 116, 1318-1328. [CrossRef] [PubMed]

124. Xu, Y.; Zhang, Q.; Miao, C.; Dongol, S.; Li, Y.; Jin, C.; Dong, R.; Li, Y.; Yang, X.; Kong, B. CCNG1 (Cyclin G1) regulation by mutant-P53 via induction of Notch3 expression promotes high-grade serous ovarian cancer (HGSOC) tumorigenesis and progression. Cancer Med. 2019, 8, 351-362. [CrossRef] [PubMed]

125. Chen, S.N.; Chang, R.; Lin, L.T.; Chern, C.U.; Tsai, H.W.; Wen, Z.H.; Li, Y.H.; Li, C.J.; Tsui, K.H. MicroRNA in Ovarian Cancer: Biology, Pathogenesis, and Therapeutic Opportunities. Int. J. Environ. Res. Public Health 2019, 16, 1510. [CrossRef] [PubMed]

126. Deb, B.; Uddin, A.; Chakraborty, S. miRNAs and ovarian cancer: An overview. J. Cell. Physiol. 2018, 233, 3846-3854. [CrossRef] [PubMed]

127. Yu, X.; Zheng, H.; Chan, M.T.; Wu, W.K. Modulation of chemoresponsiveness to platinum-based agents by microRNAs in cancer. Am. J. Cancer Res. 2017, 7, 1769-1778.

128. Boac, B.M.; Xiong, Y.; Marchion, D.C.; Abbasi, F.; Bush, S.H.; Ramirez, I.J.; Khulpateea, B.R.; Clair McClung, E.; Berry, A.L.; Bou Zgheib, N.; et al. Micro-RNAs associated with the evolution of ovarian cancer cisplatin resistance. Gynecol. Oncol. 2016, 140, 259-263. [CrossRef]

129. Jurmeister, S.; Baumann, M.; Balwierz, A.; Keklikoglou, I.; Ward, A.; Uhlmann, S.; Zhang, J.D.; Wiemann, S.; Sahin, O. MicroRNA-200c represses migration and invasion of breast cancer cells by targeting actin-regulatory proteins FHOD1 and PPM1F. Mol. Cell. Biol. 2012, 32, 633-651. [CrossRef]

130. Mezencev, R.; Wartell, R.M. Cisplatin binds to pre-miR-200b and impairs its processing to mature microRNA. Neoplasma 2018, 65, 222-227. [CrossRef]

131. Cao, L.; Wan, Q.; Li, F.; Tang, C.E. MiR-363 inhibits cisplatin chemoresistance of epithelial ovarian cancer by regulating snail-induced epithelial-mesenchymal transition. BMB Rep. 2018, 51, 456-461. [CrossRef]

132. Liu, Y.; Han, S.; Li, Y.; Liu, Y.; Zhang, D.; Li, Y.; Zhang, J. MicroRNA-20a contributes to cisplatin-resistance and migration of OVCAR3 ovarian cancer cell line. Oncol. Lett. 2017, 14, 1780-1786. [CrossRef] [PubMed]

133. Li, L.; Xu, Q.H.; Dong, Y.H.; Li, G.X.; Yang, L.; Wang, L.W.; Li, H.Y. MiR-181a upregulation is associated with epithelial-to-mesenchymal transition (EMT) and multidrug resistance (MDR) of ovarian cancer cells. Eur. Rev. Med. Pharmacol. Sci. 2016, 20, 2004-2010. [PubMed]

134. Xia, H.; Ooi, L.L.; Hui, K.M. MicroRNA-216a/217-induced epithelial-mesenchymal transition targets PTEN and SMAD7 to promote drug resistance and recurrence of liver cancer. Hepatology 2013, 58, 629-641. [CrossRef] [PubMed] 
135. Jin, P.; Liu, Y.; Wang, R. STAT3 regulated miR-216a promotes ovarian cancer proliferation and cisplatin resistance. Biosci. Rep. 2018, 38. [CrossRef] [PubMed]

136. Han, M.; Liu, M.; Wang, Y.; Chen, X.; Xu, J.; Sun, Y.; Zhao, L.; Qu, H.; Fan, Y.; Wu, C. Antagonism of miR-21 reverses epithelial-mesenchymal transition and cancer stem cell phenotype through AKT/ERK1/2 inactivation by targeting PTEN. PLoS ONE 2012, 7, e39520. [CrossRef] [PubMed]

137. Au Yeung, C.L.; Co, N.N.; Tsuruga, T.; Yeung, T.L.; Kwan, S.Y.; Leung, C.S.; Li, Y.; Lu, E.S.; Kwan, K.; Wong, K.K.; et al. Exosomal transfer of stroma-derived miR21 confers paclitaxel resistance in ovarian cancer cells through targeting APAF1. Nat. Commun. 2016, 7, 11150. [CrossRef] [PubMed]

138. Voth, W.; Jakob, U. Stress-Activated Chaperones: A First Line of Defense. Trends Biochem. Sci. 2017, 42, 899-913. [CrossRef]

139. Amoroso, M.R.; Matassa, D.S.; Agliarulo, I.; Avolio, R.; Lu,H.; Sisinni, L.; Lettini, G.; Gabra, H.; Landriscina, M.; Esposito, F. TRAP1 downregulation in human ovarian cancer enhances invasion and epithelial-mesenchymal transition. Cell Death Dis. 2016, 7, e2522. [CrossRef]

140. Amoroso, M.R.; Matassa, D.S.; Agliarulo, I.; Avolio, R.; Maddalena, F.; Condelli, V.; Landriscina, M.; Esposito, F. Stress-Adaptive Response in Ovarian Cancer Drug Resistance: Role of TRAP1 in Oxidative Metabolism-Driven Inflammation. Adv. Protein Chem. Struct. Biol. 2017, 108, 163-198. [CrossRef]

141. Aust, S.; Bachmayr-Heyda, A.; Pateisky, P.; Tong, D.; Darb-Esfahani, S.; Denkert, C.; Chekerov, R.; Sehouli, J.; Mahner, S.; Van Gorp, T.; et al. Role of TRAP1 and estrogen receptor alpha in patients with ovarian cancer -a study of the OVCAD consortium. Mol. Cancer 2012, 11, 69. [CrossRef]

142. Na, Y.; Kaul, S.C.; Ryu, J.; Lee, J.S.; Ahn, H.M.; Kaul, Z.; Kalra, R.S.; Li, L.; Widodo, N.; Yun, C.O.; et al. Stress chaperone mortalin contributes to epithelial-mesenchymal transition and cancer metastasis. Cancer Res. 2016, 76, 2754-2765. [CrossRef] [PubMed]

143. Yang, L.; Li, H.; Jiang, Y.; Zuo, J.; Liu, W. Inhibition of mortalin expression reverses cisplatin resistance and attenuates growth of ovarian cancer cells. Cancer Lett. 2013, 336, 213-221. [CrossRef] [PubMed]

144. Borovski, T.; De Sousa, E.M.F.; Vermeulen, L.; Medema, J.P. Cancer stem cell niche: The place to be. Cancer Res. 2011, 71, 634-639. [CrossRef] [PubMed]

145. Ghoneum, A.; Afify, H.; Salih, Z.; Kelly, M.; Said, N. Role of tumor microenvironment in ovarian cancer pathobiology. Oncotarget 2018, 9, 22832-22849. [CrossRef] [PubMed]

146. Yeung, T.L.; Leung, C.S.; Li, F.; Wong, S.S.; Mok, S.C. Targeting Stromal-Cancer Cell Crosstalk Networks in Ovarian Cancer Treatment. Biomolecules 2016, 6, 3. [CrossRef]

147. Hansen, J.M.; Coleman, R.L.; Sood, A.K. Targeting the tumour microenvironment in ovarian cancer. Eur. J. Cancer 2016, 56, 131-143. [CrossRef] [PubMed]

148. Zhang, B.; Chen, F.; Xu, Q.; Han, L.; Xu, J.; Gao, L.; Sun, X.; Li, Y.; Li, Y.; Qian, M.; et al. Revisiting ovarian cancer microenvironment: A friend or a foe? Protein Cell 2018, 9, 674-692. [CrossRef]

149. Sullivan, N.J.; Sasser, A.K.; Axel, A.E.; Vesuna, F.; Raman, V.; Ramirez, N.; Oberyszyn, T.M.; Hall, B.M. Interleukin-6 induces an epithelial-mesenchymal transition phenotype in human breast cancer cells. Oncogene 2009, 28, 2940-2947. [CrossRef]

150. Wang, L.; Zhang, F.; Cui, J.Y.; Chen, L.; Chen, Y.T.; Liu, B.W. CAFs enhance paclitaxel resistance by inducing EMT through the IL6/JAK2/STAT3 pathway. Oncol. Rep. 2018, 39, 2081-2090. [CrossRef]

151. Browning, L.; Patel, M.R.; Horvath, E.B.; Tawara, K.; Jorcyk, C.L. IL-6 and ovarian cancer: Inflammatory cytokines in promotion of metastasis. Cancer Manag. Res. 2018, 10, 6685-6693. [CrossRef]

152. Coffman, L.G.; Choi, Y.J.; McLean, K.; Allen, B.L.; di Magliano, M.P.; Buckanovich, R.J. Human carcinoma-associated mesenchymal stem cells promote ovarian cancer chemotherapy resistance via a BMP4/HH signaling loop. Oncotarget 2016, 7, 6916-6932. [CrossRef] [PubMed]

153. Wen, Y.; Guo, Y.; Huang, Z.; Cai, J.; Wang, Z. Adiposederived mesenchymal stem cells attenuate cisplatininduced apoptosis in epithelial ovarian cancer cells. Mol. Med. Rep. 2017, 16, 9587-9592. [CrossRef] [PubMed]

154. Moisan, F.; Francisco, E.B.; Brozovic, A.; Duran, G.E.; Wang, Y.C.; Chaturvedi, S.; Seetharam, S.; Snyder, L.A.; Doshi, P.; Sikic, B.I. Enhancement of paclitaxel and carboplatin therapies by CCL2 blockade in ovarian cancers. Mol. Oncol. 2014, 8, 1231-1239. [CrossRef] [PubMed]

155. Sato, E.; Olson, S.H.; Ahn, J.; Bundy, B.; Nishikawa, H.; Qian, F.; Jungbluth, A.A.; Frosina, D.; Gnjatic, S.; Ambrosone, C.; et al. Intraepithelial CD8+ tumor-infiltrating lymphocytes and a high CD8+/regulatory $\mathrm{T}$ 
cell ratio are associated with favorable prognosis in ovarian cancer. Proc. Natl. Acad. Sci. USA 2005, 102, 18538-18543. [CrossRef] [PubMed]

156. Odunsi, K. Immunotherapy in ovarian cancer. Ann. Oncol. Off. J. Eur. Soc. Med. Oncol. 2017, 28 , viii1-viii7. [CrossRef] [PubMed]

157. Zhang, G.; Liu, C.; Bai, H.; Cao, G.; Cui, R.; Zhang, Z. Combinatorial therapy of immune checkpoint and cancer pathways provides a novel perspective on ovarian cancer treatment. Oncol. Lett. 2019, 17, 2583-2591. [CrossRef] [PubMed]

158. Akalay, I.; Janji, B.; Hasmim, M.; Noman, M.Z.; Andre, F.; De Cremoux, P.; Bertheau, P.; Badoual, C.; Vielh, P.; Larsen, A.K.; et al. Epithelial-to-mesenchymal transition and autophagy induction in breast carcinoma promote escape from T-cell-mediated lysis. Cancer Res. 2013, 73, 2418-2427. [CrossRef]

159. Chae, Y.K.; Chang, S.; Ko, T.; Anker, J.; Agte, S.; Iams, W.; Choi, W.M.; Lee, K.; Cruz, M. Epithelial-mesenchymal transition (EMT) signature is inversely associated with T-cell infiltration in non-small cell lung cancer (NSCLC). Sci. Rep. 2018, 8, 2918. [CrossRef]

160. Chen, L.; Gibbons, D.L.; Goswami, S.; Cortez, M.A.; Ahn, Y.H.; Byers, L.A.; Zhang, X.; Yi, X.; Dwyer, D.; Lin, W.; et al. Metastasis is regulated via microRNA-200/ZEB1 axis control of tumour cell PD-L1 expression and intratumoral immunosuppression. Nat. Commun. 2014, 5, 5241. [CrossRef]

161. Lou, Y.; Diao, L.; Cuentas, E.R.; Denning, W.L.; Chen, L.; Fan, Y.H.; Byers, L.A.; Wang, J.; Papadimitrakopoulou, V.A.; Behrens, C.; et al. Epithelial-Mesenchymal Transition Is Associated with a Distinct Tumor Microenvironment Including Elevation of Inflammatory Signals and Multiple Immune Checkpoints in Lung Adenocarcinoma. Clin. Cancer Res. Off. J. Am. Assoc. Cancer Res. 2016, 22, 3630-3642. [CrossRef]

162. Alsuliman, A.; Colak, D.; Al-Harazi, O.; Fitwi, H.; Tulbah, A.; Al-Tweigeri, T.; Al-Alwan, M.; Ghebeh, H. Bidirectional crosstalk between PD-L1 expression and epithelial to mesenchymal transition: Significance in claudin-low breast cancer cells. Mol. Cancer 2015, 14, 149. [CrossRef] [PubMed]

163. Sun, L.; Wang, Q.Q.; Chen, B.; Zhao, Y.Y.; Shen, B.; Wang, H.; Xu, J.; Zhu, M.L.; Zhao, X.D.; Xu, C.G.; et al. Gastric cancer mesenchymal stem cells derived IL-8 induces PD-L1 expression in gastric cancer cells via STAT3/mTOR-c-Myc signal axis. Cell Death Dis. 2018, 9. [CrossRef] [PubMed]

164. Lamouille, S.; Connolly, E.; Smyth, J.W.; Akhurst, R.J.; Derynck, R. TGF-beta-induced activation of mTOR complex 2 drives epithelial-mesenchymal transition and cell invasion. J. Cell Sci. 2012, 125, 1259-1273. [CrossRef] [PubMed]

165. Wendt, M.K.; Balanis, N.; Carlin, C.R.; Schiemann, W.P. STAT3 and epithelial-mesenchymal transitions in carcinomas. JAK-STAT 2014, 3, e28975. [CrossRef] [PubMed]

166. Zhang, L.; Chen, Y.; Li, F.; Bao, L.; Liu, W. Atezolizumab and Bevacizumab Attenuate Cisplatin Resistant Ovarian Cancer Cells Progression Synergistically via Suppressing Epithelial-Mesenchymal Transition. Front. Immunol. 2019, 10, 867. [CrossRef]

167. Dean, M. Cancer stem cells: Redefining the paradigm of cancer treatment strategies. Mol. Interv. 2006, 6, 140-148. [CrossRef] [PubMed]

168. Morrison, R.; Schleicher, S.M.; Sun, Y.; Niermann, K.J.; Kim, S.; Spratt, D.E.; Chung, C.H.; Lu, B. Targeting the mechanisms of resistance to chemotherapy and radiotherapy with the cancer stem cell hypothesis. J. Oncol. 2011, 2011, 941876. [CrossRef] [PubMed]

169. Bhattacharya, R.; Mitra, T.; Ray Chaudhuri, S.; Roy, S.S. Mesenchymal splice isoform of CD44 (CD44s) promotes EMT/invasion and imparts stem-like properties to ovarian cancer cells. J. Cell. Biochem. 2018, 119, 3373-3383. [CrossRef] [PubMed]

170. Ip, C.K.; Li, S.S.; Tang, M.Y.; Sy, S.K.; Ren, Y.; Shum, H.C.; Wong, A.S. Stemness and chemoresistance in epithelial ovarian carcinoma cells under shear stress. Sci. Rep. 2016, 6, 26788. [CrossRef] [PubMed]

171. Shahin, S.A.; Wang, R.; Simargi, S.I.; Contreras, A.; Parra Echavarria, L.; Qu, L.; Wen, W.; Dellinger, T.; Unternaehrer, J.; Tamanoi, F.; et al. Hyaluronic acid conjugated nanoparticle delivery of siRNA against TWIST reduces tumor burden and enhances sensitivity to cisplatin in ovarian cancer. Nanomed. Nanotechnol. Biol. Med. 2018, 14, 1381-1394. [CrossRef] [PubMed]

172. Ozpolat, B.; Sood, A.K.; Lopez-Berestein, G. Liposomal siRNA nanocarriers for cancer therapy. Adv. Drug Deliv. Rev. 2014, 66, 110-116. [CrossRef] [PubMed] 
173. Deng, S.; Wong, C.K.C.; Lai, H.C.; Wong, A.S.T. Ginsenoside-Rb1 targets chemotherapy-resistant ovarian cancer stem cells via simultaneous inhibition of Wnt/beta-catenin signaling and epithelial-to-mesenchymal transition. Oncotarget 2017, 8, 25897-25914. [CrossRef] [PubMed]

174. Chau, W.K.; Ip, C.K.; Mak, A.S.; Lai, H.C.; Wong, A.S. c-Kit mediates chemoresistance and tumor-initiating capacity of ovarian cancer cells through activation of Wnt/beta-catenin-ATP-binding cassette G2 signaling. Oncogene 2013, 32, 2767-2781. [CrossRef] [PubMed]

175. Dia, V.P.; Pangloli, P. Epithelial-to-Mesenchymal Transition in Paclitaxel-Resistant Ovarian Cancer Cells Is Downregulated by Luteolin. J. Cell. Physiol. 2017, 232, 391-401. [CrossRef] [PubMed]

176. Tan, T.Z.; Miow, Q.H.; Huang, R.Y.; Wong, M.K.; Ye, J.; Lau, J.A.; Wu, M.C.; Bin Abdul Hadi, L.H.; Soong, R.; Choolani, M.; et al. Functional genomics identifies five distinct molecular subtypes with clinical relevance and pathways for growth control in epithelial ovarian cancer. EMBO Mol. Med. 2013, 5, 1051-1066. [CrossRef] [PubMed]

177. Miow, Q.H.; Tan, T.Z.; Ye, J.; Lau, J.A.; Yokomizo, T.; Thiery, J.P.; Mori, S. Epithelial-mesenchymal status renders differential responses to cisplatin in ovarian cancer. Oncogene 2015, 34, 1899-1907. [CrossRef] [PubMed]

(C) 2019 by the authors. Licensee MDPI, Basel, Switzerland. This article is an open access article distributed under the terms and conditions of the Creative Commons Attribution (CC BY) license (http://creativecommons.org/licenses/by/4.0/). 